\title{
Tax Treaties and Foreign Direct Investment: A Network Approach
}


Korea Institute of Public Finance

336, Sicheong-daero, Sejong-si, Korea

Tel: 82-44-414-2114 Fax: 82-44-414-2179

URL: www.kipf.re.kr

(C) $2015 \mathrm{KIPF}$ 


\section{Tax Treaties and \\ Foreign Direct Investment:}

A Network Approach

December 2015

Sunghoon Hong

Kipf 


\section{Contents}

1. Introduction

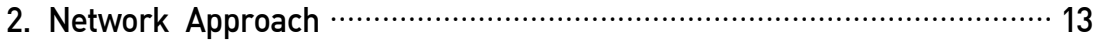

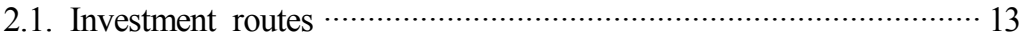

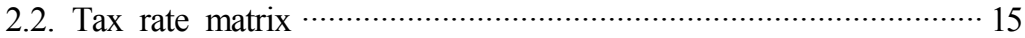

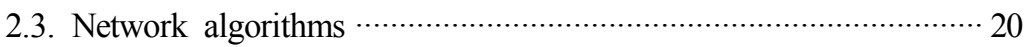

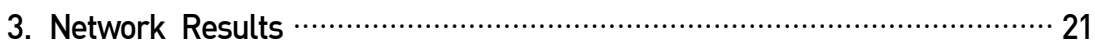

3.1. Reduced rates in pass-through countries ………........................ 23

3.2. Statutory rates in pass-through countries …….............................. 26

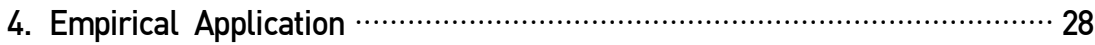

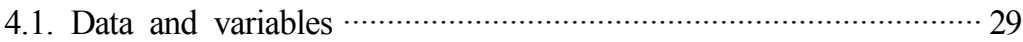

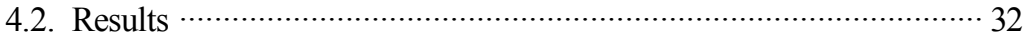

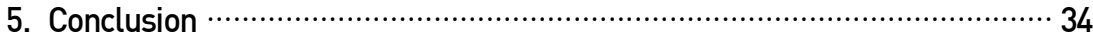




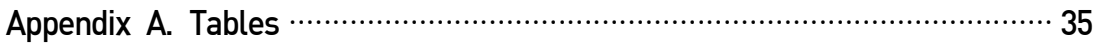

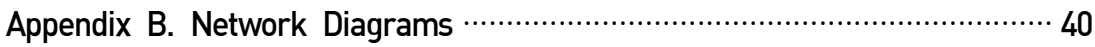

References 


\section{List of Tables}

$<$ Table 1> Selected countries and tax systems …….......................................... 16

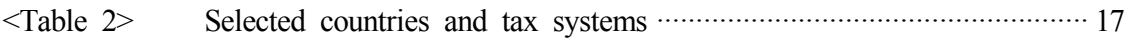

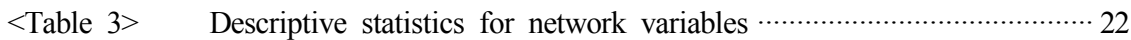

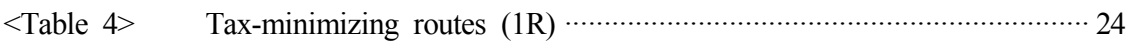

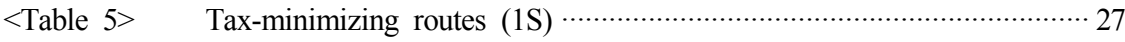

$<$ Table 6> Descriptive statistics for regression variables ……............................ 30

$<$ Table 7> FDI instock conditional on TMD variables ………………………..... 31

$<$ Table $8>\quad$ Effects of network variables (1R) on FDI instock …………............. 33

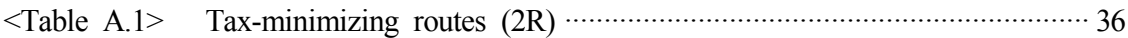

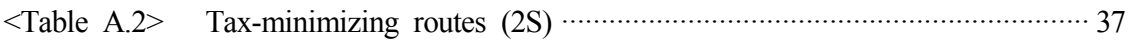

$<$ Table A.3> Effects of network variables (1S) on FDI instock ………………....... 38

$<$ Table A.4> Effects of network variables (2R) on FDI instock …........................... 39 


\section{List of Figures}

[Figure 1] Tax-minimizing routes (1R) to China ……....................................... 25

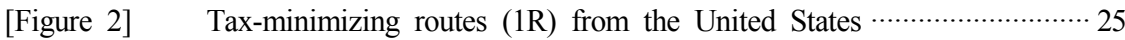

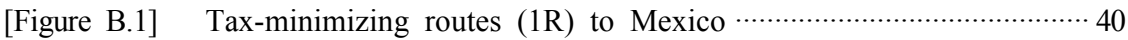

[Figure B.2] Tax-minimizing routes (1R) to Indonesia ……................................... 40

[Figure B.3] Tax-minimizing routes (1R) to Poland ……................................... 41

[Figure B.4] Tax-minimizing routes (1R) to Saudi Arabia …………………........... 41

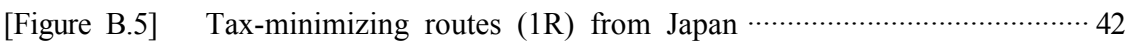

[Figure B.6] Tax-minimizing routes (1R) from France …….................................. 42

[Figure B.7] Tax-minimizing routes (1R) from Germany …….............................. 43

[Figure B.8] Tax-minimizing routes (1R) from the United Kingdom ……….......... 43 



\title{
Tax Treaties and Foreign Direct Investment: A Network Approach
}

\author{
Sunghoon Hong*
}

April 2016

\begin{abstract}
Multinational investors often reduce tax on dividends by using indirect investment routes. This paper constructs a tax rate matrix to represent a real-world network of tax treaties between 70 countries and develops network algorithms to study the structure of tax-minimizing (direct or indirect) investment routes in the tax treaty network. The treaty shopping arbitrage rate, defined as the difference between the foreign tax rates of the direct route and a tax-minimizing route, is estimated to be about 3.57 percentage points on average. In bilateral FDI data, it appears that the average inward FDI stock via a taxminimizing direct route is about 3.75 times larger than the average via a direct route that is not tax-minimizing. Empirical results confirm that the availability of a tax-minimizing direct route is positively and significantly related to FDI. By making a direct route tax-minimizing, countries can encourage FDI via the direct route and reduce the use of indirect routes through conduit countries.
\end{abstract}

JEL classification: F23, H25, H87

Keywords: tax treaty network, tax-minimizing route, treaty shopping arbitrage, foreign direct investment

*Korea Institute of Public Finance, 1924 Hannuri-daero, Sejong 30147, South Korea, sunghoonhong@kipf.re.kr. 



\section{Introduction}

The main purpose of tax treaties is to avoid, or at least to reduce, double taxation on cross-border economic activity, such as foreign direct investment (FDI). By reducing double taxation, tax treaties can help increase the netof-tax return of investors, such as multinational firms, and encourage FDI. ${ }^{1}$ Despite the expected relationship between tax treaties and FDI, empirical studies have found little evidence to support the relationship. For instance, Blonigen and Davies (2004) use an indicator variable for the presence of a tax treaty and find that the average treaty effect on FDI stock is statistically insignificant. $^{2}$

Researchers take two different approaches to resolve the puzzling relationship between tax treaties and FDI. The first approach is to use firm-level data to overcome the aggregate nature of FDI data. ${ }^{3}$ The second approach is to use network optimization techniques to understand the network effect of tax treaties on FDI. ${ }^{4}$

By following the "network" approach, in this paper, I examine the structure of tax-minimizing investment routes in a network of tax treaties between 70 countries. This tax treaty network is represented as a tax rate matrix where each entry is defined as the minimum withholding tax rate on

\footnotetext{
${ }^{1}$ Foreign "direct" investment from country $i$ to country $j$ requires that an investor in country $i$ should play an active role by owning a significant proportion (e.g., at least 10 percent) of shares of a company in country $j$. Generally, FDI is distinguished from foreign "portfolio" investment that requires no minimum threshold on ownership. However, FDI can be made with indirect ownership structures using conduit companies in countries other than $i$ and $j$. In this paper, the definition of indirect investment routes focuses on such indirect ownership structures.

${ }^{2}$ Louie and Rousslang (2008) also use a treaty dummy variable and find no significant treaty effect on the rate of return from FDI after controlling for the quality of governance in source countries. However, di Giovanni (2005) finds a positive treaty effect on cross-border mergers and acquisitions. For a survey of earlier studies, see Davies (2004).

${ }^{3}$ Weyzig (2013) uses the Dutch data on special purpose entities and finds positive treaty effects on FDI. Blonigen et al. (2014) use the US BEA data on multinational company operations and find that the average treaty effect on foreign affiliate activity is insignificant.

${ }^{4}$ Hong (2014) examines tax-minimizing investment structures in a tax treaty network between 15 selected countries. Also, van't Riet and Lejour (2015) investigate a tax treaty network within a more comprehensive set of countries.
} 


\section{0}

dividends and determined by relevant tax treaties and tax laws.

In this tax treaty network, investors can minimize tax on dividends by choosing direct investment routes (i.e., by investing directly) to 26 countries. These countries impose no withholding tax on dividends or have an imputation system under which no withholding tax may be imposed on dividends. However, investors may be able to minimize tax on dividends by choosing indirect investment routes (i.e., by investing indirectly through other countries) to the rest of the 44 countries.

I develop network algorithms to navigate in the tax treaty network and analyze tax-minimizing (direct or indirect) investment routes to these 44 countries. To limit computational burden, my network algorithms work under a constraint on the number of pass-through countries. I consider four cases depending on the maximum number of pass-through countries and the level of corporate income tax (CIT) rates in pass-through countries. Here I summarize the results in case $(1 \mathrm{R})$ when each route passes through at most 1 country and each pass-through country imposes CIT at a reduced rate. The results in the other cases are similar to those in case $(1 \mathrm{R})$.

Two network variables are introduced and calculated as follows. For a pair of countries, $T M D 1 R$ is a dummy variable indicating the existence (i.e., availability) of a tax-minimizing direct (TMD) route in case (1R), and $T S A 1 R$ is a continuous variable called the treaty shopping arbitrage (TSA) rate in case $(1 \mathrm{R})$ and defined as the difference between the foreign tax rates of the direct route and a tax-minimizing route. Thus, an investor can reduce her foreign tax rate by the treaty shopping arbitrage rate when using a tax-minimizing route. Notably, in case (1R), the average treaty shopping arbitrage rate is about 3.57 percentage points, ${ }^{5}$ which is substantial when compared with the average withholding tax rate of 5.35 percent.

Treaty shopping arbitrage is more substantial when the average is taken over the pairs of countries with no tax-minimizing direct route. In case

\footnotetext{
${ }^{5}$ In comparison, van't Riet and Lejour (2015) estimate that the average reduction of tax rates on dividends due to treaty shopping is at least 6 percentage points.
} 
(1R), for 3,033 pairs (62.8\%) of countries, the direct route is tax-minimizing. ${ }^{6}$ However, for 1,797 pairs $(37.2 \%)$ of countries, the direct route is not taxminimizing. Among the pairs of countries with no tax-minimizing direct route, while the average withholding tax rate is about 12.20 percent, the average treaty shopping arbitrage rate is about 9.59 percentage points.

In addition I examine the structure of tax-minimizing investment routes to certain source countries. For instance, in case (1R), when China is the source country, there are 31 tax-minimizing direct routes from 31 residence countries to China. Moreover, there are 590 tax-minimizing indirect routes from 38 residence countries to China. For example, there is a tax-minimizing indirect route from the United States (US) to China (CN) that passes through the United Kingdom or any one of other 17 countries. The treaty shopping arbitrage rate among routes between US and $\mathrm{CN}$ is calculated to be 4.05 percentage points.

Multinational firms can choose investment (ownership) structures that influence FDI between countries at an aggregate level. If such investors consider tax as an important factor when choosing investment structures, the structure of tax-minimizing investment routes, as analyzed in this paper, will be consistent with FDI data. By using bilateral FDI data from the United Nations Conference on Trade and Development (UNCTAD), I find that the average inward FDI stock via a direct route that is not tax-minimizing is about 1,525.89 million US dollars. In contrast, the average inward FDI stock via a tax-minimizing direct route is about 5,728.48 million US dollars, which is about 3.75 times larger than the average via a direct route that is not tax-minimizing.

By conducting a regression analysis, I investigate whether the two network variables, $T M D 1 R$ and $T S A 1 R$, can contribute to explain the patterns of inward FDI stock. Across all relevant regressions, the coefficients on $T M D 1 R$ are positive and highly significant. In other words, the availability of a tax-minimizing direct route in case $(1 \mathrm{R})$ is positively related to inward

\footnotetext{
${ }^{6}$ Given 70 countries, there are $4,830(=70 \times 69)$ pairs of residence and source countries.
} 
FDI stock. This empirical finding is consistent with a theoretical model. ${ }^{7}$ Therefore, by making a direct route tax-minimizing, countries can promote FDI via the direct route and reduce treaty shopping, i.e., the use of indirect routes through conduit countries. However, the coefficients on TSA1R show mixed signs, and are statistically insignificant in some regressions. The treaty shopping arbitrage rate in case (1R) may not be statistically related to inward FDI stock.

From a broader perspective, this paper contributes to the literature on taxation and investment of multinational firms. A cental issue in this literature has been whether and how taxation affects FDI. ${ }^{8}$ More recently, researchers focus on how tax systems, together with non-tax motives, influence location decisions and ownership structures of multinational firms. Barrios et al. (2012) examine how tax systems in residence and source countries separately influence location decisions and find that corporate taxation of foreign-source dividends in residence countries may deter entries into potential source countries. ${ }^{9}$ Mintz and Weichenrieder (2010) find that German multinational firms use indirect ownership structures through conduit countries and suggest that treaty shopping is a main reason for indirect structures. Lewellen and Robinson (2013) also discover that US multinational firms use indirect ownership structures for tax motives. Dyreng et al. (2015) find that US multinational firms are more likely to use indirect ownership structures (i.e., foreign equity holding companies) as the withholding tax rate on dividends paid from a source country to US increases. However, they find no evidence that the existence of a tax treaty between the source country and US affects the use of indirect structures.

\footnotetext{
${ }^{7}$ Hong (2014) develops a game-theoretic model where the availability of a taxminimizing direct route increases the equilibrium probability for an investor to use the direct route, which in turn positively influences FDI.

${ }^{8}$ Mooij and Ederveen (2003) provide a survey of empirical studies. For more recent studies, see Desai et al. (2004), Mutti and Grubert (2004), Becker and Riedel (2012), and Becker et al. (2012).

${ }^{9}$ For related studies, see Huizinga and Voget (2009) and Voget (2011). Devereux et al. (2015) examine the efficiency of tax relief rules (deduction, exemption, and credit systems) for foreign-source income. Dischinger and Riedel (2011) examine location decisions for intangible assets.
} 
The rest of this paper is organized as follows. Section 2 introduces a tax rate matrix to represent a tax treaty network and develops network algorithms to navigate in the network. Section 3 analyzes the structure of taxminimizing investment routes in the network and calculates network variables such as the treaty shopping arbitrage rate. Section 4 investigates the relation between FDI and the network variables. Section 5 concludes.

\section{Network Approach}

A complete directed network is a network in which each pair of nodes is connected by two links with opposite directions. Countries $i$ and $j$ can be thought of as nodes $i$ and $j$ in a complete directed network where each link $i j$ is given a weight $t_{i j}$ representing a withholding tax rate on dividends. This complete directed network can be thought of as a tax treaty network because tax treaties often determine withholding tax rates on dividends paid across countries. By constructing a tax rate matrix $T=\left[t_{i j}\right]$ to represent a tax treaty network, and by developing network algorithms to navigate in the network, I examine the structure of tax-minimizing investment routes in the tax treaty network.

\section{$2.1 \quad$ Investment routes}

An investor plans to invest in country $s$ but lives in country $h$. From this investment, the investor will earn income $m$ as dividends in country $s$ and repatriate her income to country $h$. Country $s$ is called the source country while country $h$ is called the residence (or home) country.

The investor chooses an investment route to maximize her net-of-tax income in the residence country, i.e., to minimize tax when she remits her income to country $h$. Formally, an investment route, or simply a route, is defined as a series of countries, $h, i, \ldots, j, s$, from country $h$ to country $s$. Let $R(h, s)$ denote the set of all routes from $h$ to $s$. Let $r \in R(h, s)$ denote a route. Given a route $r=h, i, \ldots, j, s$, countries $i$ through $j$ are called 


\section{4}

pass-through countries. A route $h, i, \ldots, j, s$ is often written as

$$
h \rightarrow i \rightarrow \cdots \rightarrow j \rightarrow s
$$

when it is necessary to highlight the direction of the route. The investor can choose an indirect route $h, i, \ldots, j, s$ to invest in country $s$ by establishing conduit entities in countries $i$ through $j$ and making her investment indirectly through these entities. She can also choose the direct route $h, s$ to invest in country $s$. When the investor remits her income from $s$ to $h$, the remittance route follows the reverse order of the countries in the investment route. The investor leaves no retained earnings in pass-through countries.

The investor's net-of-tax income depends on tax relief rules in the home country. I assume that the home country has a deduction or an exemption system. ${ }^{10}$ The foreign tax rate $f(r)$ of a route $r$ is defined as follows:

$$
f(r)= \begin{cases}t_{s h} & \text { if } r=h, s \\ 1-\left(1-t_{s j}\right)\left(1-t_{j}\right) \cdots\left(1-t_{i}\right)\left(1-t_{i h}\right) & \text { if } r=h, i, \ldots, j, s\end{cases}
$$

Here $t_{i}$ denotes the corporate income tax rate in country $i$ and $t_{i j}$ denotes the withholding tax rate on dividends paid from country $i$ to country $j$.

If the investor chooses a route $r$, in the residence country, the investor's net-of-tax income is $m(1-f(r))\left(1-t_{h}\right)$. Because the residence country $h$, the source country $s$, and the dividend income $m$ are given and fixed, the investor's net-of-tax income is determined by the choice of a route $r \in$ $R(h, s)$. A route $r^{*} \in R(h, s)$ is called tax-minimizing if for every $r \in R(h, s)$, $f\left(r^{*}\right) \leq f(r)$. The investor can maximize her net-of-tax income by choosing a tax-minimizing route $r^{*}$.

The investor needs to know the information about tax rates to find taxminimizing routes from the residence country to the source country. The

\footnotetext{
${ }^{10}$ This assumption implies that the investor has an incentive to use indirect routes to maximize her net-of-tax income. Alternative, if the residence country has a foreign tax credit system, the investor's net-of-tax income is determined by the greater of the foreign tax rate $f(r)$ and the domestic tax rate $t_{h}$. Thus, if the domestic tax rate is sufficiently high, the investor has no incentive to use indirect routes to increase her net-of-tax income.
} 
information about withholding tax rates on dividends can be summarized in a tax rate matrix.

\subsection{Tax rate matrix}

A tax rate matrix $T=\left[t_{i j}\right]$ shows withholding tax rates on dividends paid across national borders. ${ }^{11}$ Each tax rate $t_{i j}$ is applied for a pair of countries $i$ and $j$. If an entity in country $i$ remits dividends to an entity in country $j$, the tax agency in country $i$ imposes a withholding tax on dividends at the tax rate $t_{i j}$. Each tax rate $t_{i j}$ is determined by the tax treaty between countries $i$ and $j$ and by the national tax law of country $i$. For the sake of running network algorithms, each diagonal entry $t_{i i}$ is assumed to be zero. The corporate income tax rate in country $i$ is denoted by $t_{i}$.

Here I construct a tax rate matrix $T=\left[t_{i j}\right]$ between 70 countries, as listed in Tables 1 and 2, by using the information on tax treaties and national tax laws from Deloitte International Tax Source ${ }^{12}$ and $\mathrm{PwC}_{\mathrm{W}}$ Worldwide Tax Summaries. ${ }^{13}$ From these sources I also find the information about corporate income tax rates. Tables 1 and 2 summarize notable withholding tax (WHT) systems with minimum, median, and maximum withholding tax rates and corporate income tax (CIT) rates in the 70 countries.

Each tax rate $t_{i j}$ is determined as follows:

First, if the European Union Parent-Subsidiary Directive (EU PSD) can be applied for countries $i$ and $j$, then set $t_{i j}=0$. The EU PSD requires the exemption of withholding tax on dividends paid across EU countries, Iceland, Norway, and Switzerland. ${ }^{14}$

Second, if the EU PSD cannot be applied for at least one of countries $i$ and $j$, then check if there is a tax treaty between countries $i$ and $j$. If there

\footnotetext{
${ }^{11}$ Barrios et al. (2012, Table 2) provide a tax rate matrix of 33 European countries. Johannesen (2012, Table 1) also presents a matrix of withholding tax rates on interest paid across 28 OECD countries. However, these studies do not consider indirect investment structures, as I do in this paper.

${ }^{12}$ Deloitte website: www.dits.deloitte.com

${ }^{13} \mathrm{PwC}$ website: taxsummaries.pwc.com/uk/taxsummaries/wwts.nsf

${ }^{14}$ European Commission, Council Directive 2003/123/EC of 22 December 2003
} 
Table 1. Selected countries and tax systems

\begin{tabular}{|c|c|c|c|c|c|c|}
\hline Countries & Codes & WHT systems & Min & Med & Max & CIT \\
\hline Argentina & $\mathrm{AR}$ & Single rate $10 \%$ & 10 & 10 & 10 & 35 \\
\hline Australia & $\mathrm{AU}$ & Imputation & 0 & 0 & 0 & 30 \\
\hline Austria & $\mathrm{AT}$ & & 0 & 5 & 25 & 25 \\
\hline Belgium & $\mathrm{BE}$ & & 0 & 0 & 25 & 33 \\
\hline Bermuda & BM & No WHT & 0 & 0 & 0 & 0 \\
\hline Brazil & $\mathrm{BR}$ & No WHT & 0 & 0 & 0 & 34 \\
\hline Bulgaria & BG & & 0 & 5 & 5 & 10 \\
\hline Canada & $\mathrm{CA}$ & & 5 & 5 & 25 & 15 \\
\hline Cayman & KY & No WHT & 0 & 0 & 0 & 0 \\
\hline Chile & CL & Imputation & 0 & 0 & 0 & 22.5 \\
\hline China & $\mathrm{CN}$ & & 5 & 10 & 10 & 25 \\
\hline Colombia & $\mathrm{CO}$ & Imputation & 0 & 0 & 0 & 25 \\
\hline Croatia & HR & & 0 & 5 & 12 & 20 \\
\hline Cyprus & $\mathrm{CY}$ & No WHT & 0 & 0 & 0 & 12.5 \\
\hline Czech Republic & $\mathrm{CZ}$ & & 0 & 5 & 15 & 19 \\
\hline Denmark & DK & & 0 & 0 & 27 & 23.5 \\
\hline Ecuador & $\mathrm{EC}$ & Imputation & 0 & 0 & 0 & 22 \\
\hline Egypt & EG & & 0 & 10 & 10 & 22.5 \\
\hline Estonia & $\mathrm{EE}$ & No WHT & 0 & 0 & 0 & 20 \\
\hline Finland & FI & & 0 & 5 & 20 & 20 \\
\hline France & FR & & 0 & 0 & 30 & 33.3 \\
\hline Germany & $\mathrm{DE}$ & & 0 & 5 & 25 & 15 \\
\hline Gibraltar & GI & No WHT & 0 & 0 & 0 & 10 \\
\hline Greece & GR & & 0 & 5 & 10 & 29 \\
\hline Guernsey & GG & No WHT & 0 & 0 & 0 & 0 \\
\hline Hong Kong & HK & No WHT & 0 & 0 & 0 & 16.5 \\
\hline Hungary & $\mathrm{HU}$ & No WHT & 0 & 0 & 0 & 10 \\
\hline Iceland & IS & & 0 & 5 & 18 & 20 \\
\hline India & IN & Single rate $15 \%$ & 15 & 15 & 15 & 30 \\
\hline Indonesia & ID & & 5 & 12.5 & 20 & 25 \\
\hline Ireland & IE & & 0 & 0 & 20 & 12.5 \\
\hline Israel & IL & & 0 & 10 & 25 & 26.5 \\
\hline Italy & IT & & 0 & 5 & 26 & 27.5 \\
\hline Japan & JP & & 0 & 10 & 20 & 23.9 \\
\hline Korea & $\mathrm{KR}$ & & 0 & 7 & 20 & 22 \\
\hline
\end{tabular}


Table 2. Selected countries and tax systems

\begin{tabular}{|c|c|c|c|c|c|c|}
\hline Country & Code & WHT System & Min & Med & Max & CIT \\
\hline Latvia & LV & No WHT & 0 & 0 & 0 & 15 \\
\hline Lithuania & LT & & 0 & 5 & 15 & 15 \\
\hline Luxembourg & $\mathrm{LU}$ & & 0 & 0 & 15 & 21 \\
\hline Malaysia & MY & No WHT & 0 & 0 & 0 & 25 \\
\hline Malta & MT & No WHT & 0 & 0 & 0 & 35 \\
\hline Mauritius & $\mathrm{MU}$ & No WHT & 0 & 0 & 0 & 15 \\
\hline Mexico & MX & & 0 & 5 & 15 & 30 \\
\hline Netherlands & NL & & 0 & 0 & 15 & 25 \\
\hline New Zealand & $\mathrm{NZ}$ & Imputation & 0 & 0 & 0 & 28 \\
\hline Norway & $\mathrm{NO}$ & & 0 & 5 & 25 & 27 \\
\hline Panama & PA & & 0 & 10 & 10 & 25 \\
\hline Peru & $\mathrm{PE}$ & & 5 & 6.8 & 6.8 & 28 \\
\hline Philippines & $\mathrm{PH}$ & & 5 & 15 & 15 & 30 \\
\hline Poland & $\mathrm{PL}$ & & 0 & 5 & 19 & 19 \\
\hline Portugal & $\overline{\mathrm{PT}}$ & & 0 & 5 & 25 & 21 \\
\hline Romania & $\mathrm{RO}$ & & 0 & 5 & 16 & 16 \\
\hline Russia & RU & & 5 & 10 & 15 & 20 \\
\hline Saudi Arabia & SA & & 0 & 5 & 5 & 20 \\
\hline Singapore & SG & No WHT & 0 & 0 & 0 & 17 \\
\hline Slovakia & SK & No WHT & 0 & 0 & 0 & 22 \\
\hline Slovenia & SI & & 0 & 5 & 15 & 17 \\
\hline South Africa & $\mathrm{ZA}$ & & 5 & 5 & 15 & 28 \\
\hline Spain & $\mathrm{ES}$ & & 0 & 0 & 20 & 28 \\
\hline Sweden & $\mathrm{SE}$ & & 0 & 0 & 30 & 22 \\
\hline Switzerland & $\mathrm{CH}$ & & 0 & 0 & 35 & 8.5 \\
\hline Taiwan & TW & & 5 & 20 & 20 & 17 \\
\hline Thailand & $\mathrm{TH}$ & & 5 & 10 & 10 & 20 \\
\hline Turkey & TR & & 5 & 10 & 15 & 20 \\
\hline Ukraine & UA & & 0 & 5 & 15 & 18 \\
\hline Arab Emirates & $\mathrm{AE}$ & No WHT & 0 & 0 & 0 & 0 \\
\hline United Kingdom & GB & No WHT & 0 & 0 & 0 & 20 \\
\hline United States & US & & 0 & 5 & 30 & 35 \\
\hline Uruguay & UY & & 5 & 7 & 7 & 25 \\
\hline Venezuela & VE & Imputation & 0 & 0 & 0 & 34 \\
\hline Vietnam & VN & No WHT & 0 & 0 & 0 & 22 \\
\hline
\end{tabular}




\section{8}

is no tax treaty between $i$ and $j$, then set $t_{i j}$ equal to the withholding tax rate specified by the national tax law of country $i$.

Third, if the EU PSD cannot be applied for at least one of countries $i$ and $j$, but if there is a tax treaty between countries $i$ and $j$, then set $t_{i j}$ equal to the minimum of the rates specified by the tax treaty between countries $i$ and $j$ and by the national tax law of country $i$.

A tax treaty may specify a system of tax rates on dividends depending on the percentage of shares. Given a system of tax rates, I assume that the minimum tax rate is applied. For example, according to the tax treaty between China (CN) and the United Kingdom (GB), if a Chinese entity pays dividends to a British entity that holds at least 25 percent of its shares, the withholding tax rate is 5 percent. Otherwise, the tax rate is 10 percent. In this case, the minimum tax rate of 5 percent is applied, i.e., for $i=\mathrm{CN}$ and $j=\mathrm{GB}, t_{i j}=5$.

Moreover, a tax treaty may include the limitation on benefits (LOB) clause, specifying additional residency requirements to obtain the benefits of the tax treaty. If the $\mathrm{LOB}$ clause specifies that the minimum tax rate can only be applied to certain pension funds, I take the next lowest tax rate for the matrix. Otherwise, I assume that the minimum tax rate is applied. For instance, according to the tax treaty (amended and signed in 2010) between the United States (US) and Hungary (HU), the minimum tax rate is zero percent, but this rate can only be applied to pension funds qualified by the LOB clause of the tax treaty. The next lowest rate is 5 percent, which can be applied to other corporate entities. So, for $i=\mathrm{US}$ and $j=\mathrm{HU}$, it is assumed that $t_{i j}=5$. However, according to the tax treaty between the United States (US) and Japan (JP), the minimum tax rate is zero percent, and this rate can be applied to pension funds as well as companies holding more than 50 percent of shares for a period longer than 12 months. So, for $i=$ US and $j=\mathrm{JP}$, it is assumed that $t_{i j}=0$.

In addition to the general rules explained so far, I consider the following specific cases to construct the tax rate matrix. 
Subnational (state, province, etc.) governments may also impose withholding taxes on dividends. However, it is an onerous task to find out the withholding tax systems of all the subnational governments in 70 countries. Even if a subnational government imposes a withholding tax, the tax rate is usually very low. Therefore, I only consider withholding taxes imposed by national (federal) governments.

There is no withholding tax on dividends in India. However, India imposes a dividend distribution tax at the rate of 15 percent. Hence, it is realistic to assume that the withholding tax rate is 15 percent in India.

Australia and New Zealand have dividend imputation systems under which no withholding tax may be imposed on dividends distributed by companies that already pay corporate taxes. Chile, Colombia, Ecuador, and Venezuela also have such imputation systems. I assume that these countries impose no withholding tax on dividends.

Belgium imposes no withholding tax on dividends paid to entities resident in a country with a tax treaty. Ireland has a similar rule for withholding tax exemption. In Denmark the withholding tax rate is no greater than 15 percent if dividends are paid to shareholders resident in a country with a tax treaty.

In the tax rate matrix as constructed above, even without using a network algorithm, we can find that the investor can minimize tax on dividends by investing directly to 26 countries among all the countries in Tables 1 and 2. In particular, 18 countries impose no withholding tax on dividends and 6 countries have a dividend imputation system. No withholding tax may be imposed on dividends under a dividend imputation system. Also, 2 countries have a withholding tax system with a single rate for all countries.

However, the investor may be able to minimize tax on dividends by investing indirectly to the rest of the 44 countries. With the information about tax rates at hand, the investor needs to develop network algorithms to find tax-minimizing investment routes to these 44 countries. 


\subsection{Network algorithms}

Given a tax rate matrix $T=\left[t_{i j}\right]$ and a pair $(h, s)$ of residence and source countries, the investor can find tax-minimizing routes from country $h$ to country $s$ by using a network algorithm. Here I propose network algorithms that work under a constraint on the number of pass-through countries. Each network algorithm repeats the following three steps for all pairs of residence and source countries. Let $(h, s)$ be a pair of countries and let $k \geq 1$ be a positive integer.

Step 1. Build a list of all routes from country $h$ to country $s$ under the constraint that the number of pass-through countries in each route is at most $k$ and compute the net-of-tax income for each route.

Step 2. Find the maximum net-of-tax income among all routes in the list.

Step 3. Find and list all the routes from $h$ to $s$ that achieve the maximum net-of-tax income.

Given 70 countries, there are $4,830(=70 \times 69)$ pairs of residence and source countries. If $k=1$, there is at most one pass-through country in each route. Thus, the list of all routes includes an indirect route $h, j, s$ with pass-through country $j$ and the direct route $h, s$. Given 70 countries, there are $69(=68+1)$ routes in the list of Step 1 .

If $k=2$, there are at most two pass-through countries in each route. Thus, the list of all routes includes an indirect route $h, i, j, s$ with pass-through countries $i$ and $j$, an indirect route $h, j, s$ with pass-through country $j$, and the direct route $h, s$. Given 70 countries, there are 4,625 $(=68 \times 67+68+1)$ routes in the list of Step 1.

As $k$ increases, the number of routes in the list of Step 1 grows exponentially. ${ }^{15}$ Because the net-of-tax income is computed and compared for each route in the list, as $k$ increases, the computational burden (or running time)

\footnotetext{
${ }^{15}$ The number of routes in the list is approximately equal to the number of countries to the power $k$.
} 
of the algorithm increases exponentially. To limit the computational burden, I will use network algorithms with $k=1$ and $k=2 .^{16}$

\section{Network Results}

For an indirect route, the net-of-tax income depends on corporate income tax (CIT) rates in pass-through countries. I consider two different scenarios about CIT rates. In the first scenario, every pass-through country imposes CIT at a reduced rate of 1 percent. In the second scenario, every passthrough country imposes CIT at the statutory rate. For each scenario, I examine two cases depending on whether $k=1$ or $k=2$. Here $k$ denotes the maximum possible number of pass-through countries in a route. I will distinguish between these four cases as follows: $(k \mathrm{R})$ represents the case when there are at most $k$ pass-through countries in a route and each pass-through country imposes CIT at the reduced rate; $(k \mathrm{~S})$ represents the case when there are at most $k$ pass-through countries in a route and each pass-through country imposes CIT at the statutory rate.

Now I introduce two groups of network variables. For a pair of countries $i$ and $j$, if there is a tax-minimizing direct (TMD) route $i \rightarrow j$ in case (1R), $T M D 1 R_{i j}=1$, and otherwise, $T M D 1 R_{i j}=0$. Also, $T M D 1 S_{i j}, T M D 2 R_{i j}$, and $T M D 2 S_{i j}$ are defined similarly in cases (1S), (2R), and (2S).

For a pair of countries $i$ and $j$, the treaty shopping arbitrage (TSA) rate among routes from $i$ to $j$ in case $(1 \mathrm{R})$ is defined as $T S A 1 R_{i j}=t_{j i}-f\left(r^{*}\right)$, where $r^{*}$ is a tax-minimizing route from $i$ to $j$ in case (1R). In words, the treaty shopping arbitrage rate among routes between a pair of residence and source countries is defined as the difference between the foreign tax rates of the direct route and a tax-minimizing route. An investor can reduce her foreign tax rate by the TSA rate by using a tax-minimizing route. If the direct route is tax-minimizing, the TSA rate is zero. Otherwise, the TSA

\footnotetext{
${ }^{16}$ It may not be unrealistic to assume that $k \leq 2$. Mintz and Weichenrieder (2010, Table 4.4) show that only 0.2 percent of German multinational firms use cross-border investment routes (ownership chains) with three or more pass-through countries.
} 
Table 3. Descriptive statistics for network variables

\begin{tabular}{c|c|c|c|c|c}
\hline Variables & Obs & Mean & Std. Dev. & Min & Max \\
\hline$T M D 1 R_{i j}$ & 4,830 & 0.63 & 0.48 & 0 & 1 \\
$T M D 1 S_{i j}$ & 4,830 & 0.75 & 0.43 & 0 & 1 \\
$T M D 2 R_{i j}$ & 4,830 & 0.61 & 0.49 & 0 & 1 \\
$T M D 2 S_{i j}$ & 4,830 & 0.75 & 0.43 & 0 & 1 \\
\hline$T S A 1 R_{i j}$ & 4,830 & 3.57 & 6.23 & 0 & 34 \\
$T S A 1 S_{i j}$ & 4,830 & 2.29 & 5.03 & 0 & 30 \\
$T S A 2 R_{i j}$ & 4,830 & 3.66 & 6.27 & 0 & 34 \\
$T S A 2 S_{i j}$ & 4,830 & 2.29 & 5.03 & 0 & 30 \\
\hline$W H T_{j i}$ & 4,830 & 5.35 & 7.13 & 0 & 35 \\
\hline
\end{tabular}

rate is a positive number calculated in percentage points. Also, $T S A 1 S_{i j}$, $T S A 2 R_{i j}$, and $T S A 2 S_{i j}$ are defined similarly in cases (1S), (2R), and (2S).

Table 3 presents descriptive statistics for network variables and withholding tax rates, denoted by $W H T_{j i}=t_{j i}$. Notably, on average, the treaty shopping arbitrage rate in case $(1 \mathrm{R})$ is about 3.57 percentage points, which is substantial when compared with the withholding tax rate of 5.35 percent.

Treaty shopping arbitrage is more substantial when the average is taken over the pairs of countries with no tax-minimizing direct route. In case $(1 \mathrm{R})$, for 3,033 pairs $(62.8 \%)$ of countries $i$ and $j$, the direct route $i \rightarrow j$ is taxminimizing. However, for 1,797 pairs (37.2\%) of countries $i$ and $j$, the direct route $i \rightarrow j$ is not tax-minimizing. Among these 1,797 pairs with no taxminimizing direct route, while the average withholding tax rate is about 12.20 percent, the average treaty shopping arbitrage rate is about 9.59 percentage points.

In case $(2 \mathrm{R})$, for 1,876 pairs $(38.8 \%)$ of countries $i$ and $j$, the direct route $i \rightarrow j$ is not tax-minimizing. Among these 1,876 pairs, while the average withholding tax rate is about 11.95 percent, the average treaty shopping arbitrage rate is about 9.42 percentage points.

In cases (1S) and (2S), for 1,193 pairs (24.7\%) of countries $i$ and $j$, the direct route $i \rightarrow j$ is not tax-minimizing. Among these 1,193 pairs, while the average withholding tax rate is about 14.95 percent, the average treaty shopping arbitrage rate is about 9.29 percentage points. 


\subsection{Reduced rates in pass-through countries}

As mentioned in Section 2.2, investors can minimize tax on dividends by investing directly to 26 countries (with no WHT, dividend imputation, or single-rate systems) among the 70 countries. However, investors may be able to minimize tax on dividends by investing indirectly to the rest of the 44 countries.

Table 4 summarizes the result for these 44 countries in case (1R) when each route passes through at most 1 country and each pass-through country imposes CIT at the reduced rate. In Table 4, column "Direct" shows the number of tax-minimizing direct routes to each source country. ${ }^{17}$ Because there is only one direct route between a pair of residence and source countries, this number coincides with the number of residence countries with taxminimizing direct routes to each source country. Column "Indirect" shows the number of tax-minimizing indirect routes and column "Indirect Home" shows the number of residence countries with tax-minimizing indirect routes to each source country. Column "TSA Mean" shows the average of TSA rates for each source country. ${ }^{18}$

As shown in Table 4, when China (CN) is the source country, there are 31 tax-minimizing direct routes in case (1R). Moreover, there are 590 taxminimizing indirect routes from 38 residence countries to China. An example of such indirect routes is

$$
\mathrm{US} \rightarrow \mathrm{GB} \rightarrow \mathrm{CN}
$$

and GB can be replaced with any one of the following 17 countries: BE, DK, EC, EE, FI, FR, DE, HK, IE, LV, MT, MU, MX, NL, SG, SE, VE. In case $(1 \mathrm{R})$ the treaty shopping arbitrage rate among routes between US and CN is 4.05 percentage points.

Figure 1 shows a network diagram of tax-minimizing investment routes to China $(\mathrm{CN})$ in case $(1 \mathrm{R})$. In Figure 1, the source country (CN) is marked in

\footnotetext{
${ }^{17}$ For country $j$, the number in column "Direct" is calculated as $\sum_{i \neq j} T M D 1 R_{i j}$.

${ }^{18}$ For country $j$, TSA Mean is calculated as $\sum_{i \neq j} T S A 1 R_{i j} /(n-1)$, where $n$ is the number of all countries.
} 
Table 4. Tax-minimizing routes (1R)

\begin{tabular}{|c|c|c|c|c|}
\hline Source & Direct & Indirect & Indirect Home & TSA Mean \\
\hline AT & 33 & 464 & 36 & 6.83 \\
\hline $\mathrm{BE}$ & 61 & 162 & 8 & 2.78 \\
\hline BG & 30 & 398 & 39 & 2.26 \\
\hline $\mathrm{CA}$ & 40 & 494 & 29 & 4.46 \\
\hline $\mathrm{CN}$ & 31 & 590 & 38 & 2.11 \\
\hline $\mathrm{HR}$ & 31 & 426 & 38 & 4.99 \\
\hline $\mathrm{CZ}$ & 31 & 387 & 38 & 4.81 \\
\hline DK & 39 & 410 & 30 & 7.41 \\
\hline EG & 5 & 232 & 64 & 7.84 \\
\hline FI & 34 & 415 & 35 & 6.01 \\
\hline FR & 38 & 391 & 31 & 5.78 \\
\hline $\mathrm{DE}$ & 31 & 386 & 38 & 6.62 \\
\hline GR & 30 & 398 & 39 & 4.51 \\
\hline IS & 30 & 398 & 39 & 8.06 \\
\hline ID & 1 & 68 & 68 & 8.24 \\
\hline IE & 54 & 245 & 15 & 4.13 \\
\hline IL & 5 & 220 & 64 & 12.71 \\
\hline IT & 31 & 386 & 38 & 7.35 \\
\hline JP & 9 & 318 & 60 & 10.62 \\
\hline KR & 25 & 441 & 44 & 4.84 \\
\hline LT & 32 & 411 & 37 & 6.13 \\
\hline $\mathrm{LU}$ & 35 & 438 & 34 & 4.14 \\
\hline MX & 19 & 610 & 50 & 5.04 \\
\hline NL & 40 & 391 & 29 & 4.07 \\
\hline $\mathrm{NO}$ & 33 & 433 & 36 & 7.59 \\
\hline $\mathrm{PA}$ & 1 & 68 & 68 & 8.28 \\
\hline $\mathrm{PE}$ & 31 & 38 & 38 & 0.58 \\
\hline $\mathrm{PH}$ & 9 & 107 & 60 & 5.03 \\
\hline $\mathrm{PL}$ & 31 & 421 & 38 & 6.36 \\
\hline $\mathrm{PT}$ & 30 & 398 & 39 & 8.06 \\
\hline $\mathrm{RO}$ & 31 & 421 & 38 & 6.41 \\
\hline $\mathrm{RU}$ & 27 & 562 & 42 & 3.91 \\
\hline SA & 16 & 121 & 53 & 3.07 \\
\hline SI & 30 & 398 & 39 & 6.29 \\
\hline$\overline{\mathrm{ZA}}$ & 40 & 528 & 29 & 3.30 \\
\hline $\mathrm{ES}$ & 38 & 457 & 31 & 4.75 \\
\hline SE & 36 & 391 & 33 & 7.49 \\
\hline $\mathrm{CH}$ & 36 & 458 & 33 & 6.36 \\
\hline TW & 17 & 218 & 52 & 6.60 \\
\hline TH & 69 & 0 & 0 & 0.00 \\
\hline TR & 15 & 446 & 54 & 5.20 \\
\hline UA & 9 & 340 & 60 & 5.98 \\
\hline US & 12 & 393 & 57 & 11.97 \\
\hline UY & 13 & 350 & 56 & 0.85 \\
\hline
\end{tabular}

Note: (1R) at most 1 pass-through country and Reduced CIT rates 
Figure 1. Tax-minimizing routes (1R) to China

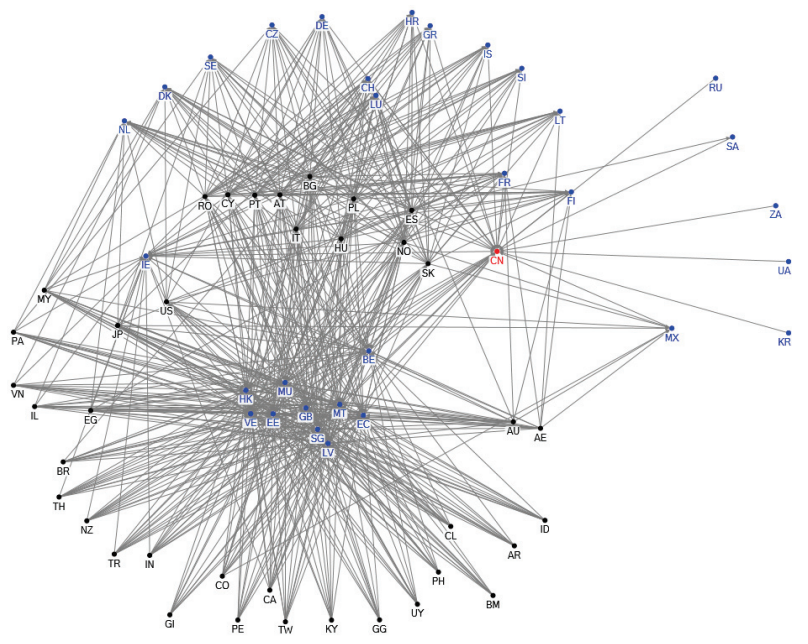

Note: source in red; countries with tax-minimizing direct routes in blue

Figure 2. Tax-minimizing routes (1R) from the United States

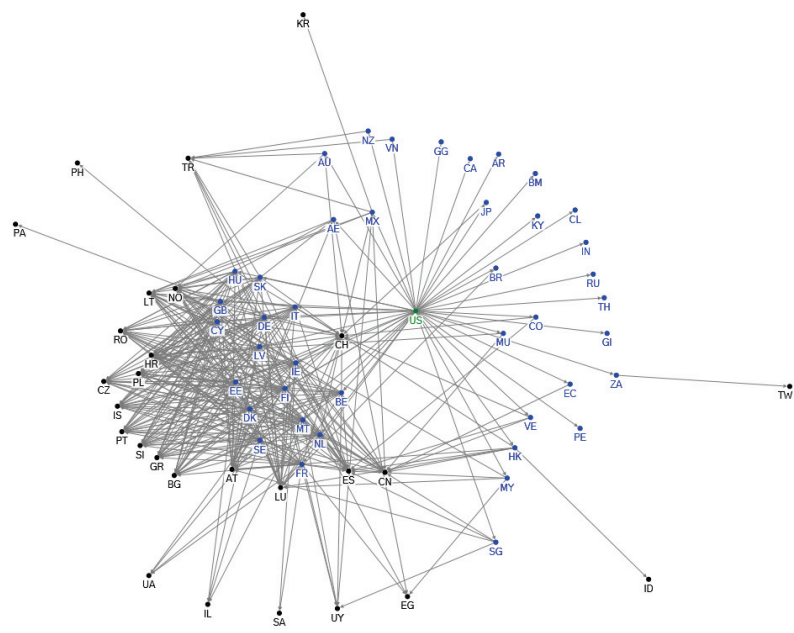

Note: residence in green; countries with tax-minimizing direct routes in blue 
red and residence countries with tax-minimizing direct routes to the source country are marked in blue. Residence countries with tax-minimizing indirect routes to the source country are marked in black. Each arrow shows the direction of a route.

The structure of tax-minimizing investment routes can also be examined from the perspective of a residence country. Figure 2 shows a network diagram of tax-minimizing investment routes from the United States (US) in case (1R). In Figure 2, the residence country (US) is marked in green and source countries with tax-minimizing direct routes from the residence country are marked in blue. Source countries with tax-minimizing indirect routes from the residence country are marked in black. Each arrow shows the direction of a route.

In Appendix A, Table A.1 summarizes the result in case (2R) when each route passes through at most 2 countries and each pass-through country imposes CIT at the reduced rate. Interestingly, when $\mathrm{KR}, \mathrm{PE}, \mathrm{PH}, \mathrm{SA}$, or $\mathrm{UA}$ is the source country, there are tax-minimizing indirect routes with 2 pass-through countries. However, for the rest of the countries, even if it is possible for a route to pass through 2 countries, every tax-minimizing route passes through at most 1 country.

In Appendix B, Figures B.1 through B.4 show network diagrams of taxminimizing investment routes to Mexico, Indonesia, Poland, and Saudi Arabia, respectively, in case $(1 \mathrm{R})$. These four countries and China are the countries with the largest net inward FDI stock.

Figures B.5 through B.8 show network diagrams of tax-minimizing investment routes from Japan, France, Germany, and the United Kingdom, respectively, in case (1R). These four countries and the United States are the countries with the largest net outward FDI stock.

\subsection{Statutory rates in pass-through countries}

Table 5 summarizes the result for the 44 countries in case (1S) when each route passes through at most 1 country and each pass-through country im- 
Table 5. Tax-minimizing routes (1S)

\begin{tabular}{|c|c|c|c|c|}
\hline Source & Direct & Indirect & Indirect Home & TSA Mean \\
\hline $\mathrm{AT}$ & 33 & 68 & 68 & 7.35 \\
\hline $\mathrm{BE}$ & 61 & 68 & 68 & 2.90 \\
\hline $\mathrm{BG}$ & 69 & 152 & 39 & 0.00 \\
\hline $\mathrm{CA}$ & 40 & 68 & 68 & 4.86 \\
\hline $\mathrm{CN}$ & 33 & 37 & 37 & 1.54 \\
\hline $\mathrm{HR}$ & 43 & 28 & 28 & 0.88 \\
\hline $\mathrm{CZ}$ & 46 & 37 & 37 & 2.61 \\
\hline DK & 48 & 27 & 27 & 3.80 \\
\hline EG & 5 & 68 & 68 & 8.77 \\
\hline FI & 34 & 68 & 68 & 6.52 \\
\hline $\mathrm{FR}$ & 38 & 68 & 68 & 6.23 \\
\hline $\mathrm{DE}$ & 48 & 37 & 37 & 4.42 \\
\hline GR & 38 & 38 & 38 & 2.25 \\
\hline IS & 39 & 32 & 32 & 3.59 \\
\hline ID & 34 & 67 & 67 & 4.25 \\
\hline IE & 54 & 68 & 68 & 4.35 \\
\hline IL & 39 & 30 & 30 & 4.07 \\
\hline IT & 40 & 37 & 37 & 5.14 \\
\hline $\mathrm{JP}$ & 21 & 59 & 59 & 7.14 \\
\hline KR & 34 & 67 & 67 & 4.16 \\
\hline LT & 32 & 68 & 68 & 6.67 \\
\hline $\mathrm{LU}$ & 52 & 66 & 34 & 2.17 \\
\hline MX & 19 & 68 & 68 & 5.77 \\
\hline NL & 50 & 28 & 28 & 2.39 \\
\hline $\mathrm{NO}$ & 47 & 26 & 26 & 3.67 \\
\hline $\mathrm{PA}$ & 9 & 66 & 66 & 4.35 \\
\hline $\mathrm{PE}$ & 69 & 268 & 68 & 0.00 \\
\hline $\mathrm{PH}$ & 20 & 67 & 67 & 3.55 \\
\hline $\mathrm{PL}$ & 31 & 68 & 68 & 6.91 \\
\hline $\mathrm{PT}$ & 37 & 38 & 38 & 5.80 \\
\hline $\mathrm{RO}$ & 31 & 68 & 68 & 6.96 \\
\hline $\mathrm{RU}$ & 64 & 61 & 20 & 0.14 \\
\hline $\mathrm{SA}$ & 69 & 260 & 66 & 0.00 \\
\hline SI & 39 & 38 & 38 & 4.03 \\
\hline $\mathrm{ZA}$ & 47 & 22 & 22 & 0.32 \\
\hline ES & 46 & 30 & 30 & 2.96 \\
\hline $\mathrm{SE}$ & 52 & 24 & 24 & 3.91 \\
\hline $\mathrm{CH}$ & 50 & 32 & 32 & 4.45 \\
\hline TW & 21 & 48 & 48 & 1.17 \\
\hline $\mathrm{TH}$ & 69 & 268 & 68 & 0.00 \\
\hline TR & 41 & 53 & 53 & 2.03 \\
\hline UA & 38 & 63 & 63 & 3.80 \\
\hline US & 44 & 25 & 25 & 4.78 \\
\hline UY & 69 & 220 & 56 & 0.00 \\
\hline
\end{tabular}

Note: (1S) at most 1 pass-through country and Statutory CIT rates 


\section{8}

poses CIT at the statutory rate.

As shown in Table 5, when China (CN) is the source country, there are 33 tax-minimizing direct routes in case (1S). Moreover, there are 37 taxminimizing indirect routes from 37 residence countries to China. An example of such indirect routes is

$$
\mathrm{US} \rightarrow \mathrm{AE} \rightarrow \mathrm{CN}
$$

and AE is the only pass-through country from US to CN. Furthermore, AE is the only pass-through country in the other tax-minimizing indirect routes to $\mathrm{CN}$. In case (1S) the treaty shopping arbitrage rate among routes between US and $\mathrm{CN}$ is 3.00 percentage points.

In case $(1 \mathrm{~S})$ every tax-minimizing indirect route passes through any one of the following 6 countries: BM, KY, GG, HU, CH, AE. All these countries except for $\mathrm{HU}$ and $\mathrm{CH}$ impose no CIT while $\mathrm{HU}$ and $\mathrm{CH}$ impose $\mathrm{CIT}$ at relatively low statutory rates, 10 and 8.5 percent, respectively.

In Appendix A, Table A.2 summarizes the result in case (2S). Interestingly, the result in case $(2 \mathrm{~S})$ is essentially the same as the result in case (1S), except for the existence of tax-minimizing indirect routes with 2 pass-through countries. Because BM, KY, GG, and AE impose no CIT and no WHT, by adding one of these countries into a tax-minimizing indirect route with 1 pass-through country, we can construct a tax-minimizing indirect route with 2 pass-through countries. However, this sort of extension does not change the net-of-tax income. Hence, for each pair of residence and source countries, the direct route is tax-minimizing in case $(1 \mathrm{~S})$ if and only if it is tax-minimizing in case $(2 \mathrm{~S})$. Furthermore, the treaty shopping arbitrage rate in case (1S) is equal to that in case $(2 \mathrm{~S})$.

\section{Empirical Application}

Multinational firms can choose investment (ownership) structures that influence foreign direct investment (FDI) between countries at an aggregate level. If such investors consider tax as an important factor when choosing invest- 
ment structures,${ }^{19}$ the results of the network analysis in Section 3 will turn out to be consistent with FDI data. Here I investigate whether two groups of network variables, calculated in Section 3, help explain the patterns of FDI.

\subsection{Data and variables}

For a pair of countries $i$ and $j$, the dependent variable $I N S T K_{i j}$ is defined as the inward FDI stock from $i$ to $j$ in millions of US dollars. These bilateral FDI data are obtained from the UNCTAD. ${ }^{20}$ Because all the 70 countries except for Gibraltar (GI) and Guernsey (GG) are included in the bilateral FDI data, there are $4,556(=68 \times 67)$ pairs of residence and source countries.

Table 6 provides descriptive statistics for $I N S T K_{i j}$ and for independent variables including the network variables. As mentioned in Section 3.2, it turns out that the network variables in case $(2 \mathrm{~S})$ are the same as those in case (1S). Henceforth, I will refrain from reporting the results with the network variables in case $(2 \mathrm{~S})$.

Two groups of network variables, TMD and TSA, are introduced and calculated in the network analysis. These network variables are defined for a pair of countries $i$ and $j$.

Firstly, each TMD variable is an indicator variable for the existence of a tax-minimizing direct route. In case $(1 \mathrm{R})$, if there is a tax-minimizing direct (TMD) route from $i$ to $j, T M D 1 R_{i j}=1$, and otherwise, $T M D 1 R_{i j}=0$.

I expect that each TMD variable is positively related to inward FDI stock. When the direct route is tax-minimizing between a pair of residence and source countries, investors will consider the direct route more attractive than indirect routes, and thus, they will use the direct route more frequently. Hong (2014) develops a game-theoretic model of treaty shopping and tax auditing between an investor and a tax agency, where the existence (i.e.,

\footnotetext{
${ }^{19}$ For instance, Mintz and Weichenrieder (2010), Lewellen and Robinson (2013), and Dyreng et al. (2015) discover that multinational firms use indirect ownership structures for tax motives.

${ }^{20}$ Because network variables are calculated without time-series dimension, I focus on cross-sectional data for year 2012 or the latest year available.
} 
Table 6. Descriptive statistics for regression variables

\begin{tabular}{c|c|c|c|c|c}
\hline Variables & Obs & Mean & Std. Dev. & Min & Max \\
\hline$I N S T K_{i j}$ & 4,556 & $4,146.52$ & $23,234.57$ & $-12,850.94$ & $592,273.20$ \\
\hline$T M D 1 R_{i j}$ & 4,556 & 0.62 & 0.48 & 0 & 1 \\
$T M D 1 S_{i j}$ & 4,556 & 0.75 & 0.43 & 0 & 1 \\
$T M D 2 R_{i j}$ & 4,556 & 0.61 & 0.49 & 0 & 1 \\
\hline$T S A 1 R_{i j}$ & 4,556 & 3.49 & 6.05 & 0 & 34 \\
$T S A 1 S_{i j}$ & 4,556 & 2.21 & 4.85 & 0 & 30 \\
$T S A 2 R_{i j}$ & 4,556 & 3.58 & 6.09 & 0 & 34 \\
\hline WHT $_{j i}$ & 4,556 & 5.31 & 6.97 & 0 & 35 \\
CIT $_{j}$ & 4,556 & 21.67 & 7.86 & 0 & 35 \\
IIT $_{i}$ & 4,556 & 21.67 & 7.86 & 0 & 35 \\
\hline TINSTK $_{j}$ & 4,556 & $312,426.70$ & $445,782.00$ & $3,913.11$ & $2,650,832.00$ \\
TOUTST $_{i}$ & 4,556 & $323,819.20$ & $650,720.20$ & 361.51 & $4,453,307.00$ \\
\hline
\end{tabular}

availability) of a tax-minimizing direct route increases the investor's equilibrium probability to use the direct route. This equilibrium behavior leads to increased FDI between residence and source countries at an aggregate level.

Secondly, each TSA variable is a continuous variable specifying the difference between the foreign tax rates of the direct route and a tax-minimizing route. In case (1R), the treaty shopping arbitrage (TSA) rate among routes from $i$ to $j$ is defined as $T S A 1 R_{i j}=t_{j i}-f\left(r^{*}\right)$, where $r^{*}$ is a tax-minimizing route from $i$ to $j$.

I expect that each TSA variable is negatively related to inward FDI stock. When the direct route is not tax-minimizing between a pair of residence and source countries, a TSA variable takes a positive value. Moreover, as the TSA variable increases, by definition, the difference becomes larger between the foreign tax rates of the direct route and a tax-minimizing route. Thus, investors will consider the direct route less attractive than tax-minimizing indirect routes. This can reduce FDI between residence and source countries at an aggregate level.

However, it is also possible that a TSA variable is not significantly related to inward FDI stock. In the game-theoretic model of Hong (2014), the TSA variable (i.e., the difference between the foreign tax rates of the direct route and a tax-minimizing route) does not affect the investor's equilibrium 
Table 7. FDI instock conditional on TMD variables

\begin{tabular}{c|c|c|c|c}
\hline FDI instock & Conditional on & Obs & Mean & Std. Dev. \\
\hline INSTK & $T M D 1 R_{i j}=0$ & $1,715(37.6 \%)$ & $1,525.89$ & $10,300.17$ \\
& $T M D 1 R_{i j}=1$ & $2,841(62.4 \%)$ & $5,728.48$ & $28,198.64$ \\
\hline$I N S T K_{i j}$ & $T M D 1 S_{i j}=0$ & $1,118(24.5 \%)$ & 961.11 & $5,016.57$ \\
& $T M D 1 S_{i j}=1$ & $3,438(75.5 \%)$ & $5,182.38$ & $26,512.18$ \\
\hline$I N S T K_{i j}$ & $T M D 2 R_{i j}=0$ & $1,790(39.3 \%)$ & $1,481.87$ & $10,087.54$ \\
& $T M D 2 R_{i j}=1$ & $2,766(60.7 \%)$ & $5,870.92$ & $28,564.29$ \\
\hline
\end{tabular}

probability, but affects the tax agency's equilibrium audit probability. In this model, when the TSA variable changes, the tax agency adjusts the equilibrium audit probability, and the investor stays indifferent between the direct route and tax-minimizing indirect routes.

In addition there are three tax rate variables. All tax rates are in percentage. The withholding tax rate on dividends paid from $j$ to $i$ is denoted by $W H T_{j i}$. Withholding tax rates are from the tax rate matrix constructed in Section 2.2. The corporate income tax rate in source country $j$ is denoted by $C I T_{j}$ whereas the corporate income tax rate in residence country $i$ is denoted by $C I T_{i}$. Corporate income tax rates are from Deloitte International Tax Source and PwC Worldwide Tax Summaries.

The source gravity variable $T I N S T K_{j}$ is defined as the total inward FDI stock to source country $j$ in millions of US dollars. The residence gravity variable $\operatorname{TOUTSTK}_{i}$ is the total outward FDI stock from residence country $i$ in millions of US dollars.

Before proceeding to regression results, it is worthwhile to examine patterns in the data. Table 7 provides descriptive statistics for inward FDI stock INST $K_{i j}$ conditional on the existence of a tax-minimizing direct route from country $i$ to country $j$. For 1,715 pairs $(37.6 \%)$ of countries $i$ and $j$, the direct route $i \rightarrow j$ is not tax-minimizing in case (1R). The average inward FDI stock via a direct route that is not tax-minimizing is about 1,525.89 million US dollars. In contrast, for 2,841 pairs (62.4\%) of countries $i$ and $j$, there is a tax-minimizing direct route $i \rightarrow j$ in case (1R). The average inward FDI stock via a tax-minimizing direct route is about 5,728.48 million US dollars, 
which is about 3.75 times larger than the average via a direct route that is not tax-minimizing.

\subsection{Results}

As mentioned in the introduction, previous studies used a dummy variable for the presence of a tax treaty and found little evidence for the relationship between tax treaties and FDI. ${ }^{21}$ I also included the treaty dummy variable in my data set and found no significant treaty effect on inward FDI stock, as reported by the previous studies. Hence, I will focus on the results with network variables.

Table 8 presents the results of regressions with network variables TMD1R and $T S A 1 R$. Each regression includes dummy variables for residence (home) and source countries as well as gravity variables to control for the factors that may also influence FDI at an aggregate level.

Column (1) is a benchmark without the network variables. The coefficient on the WHT rates in (1) is negative and significant at the 1 percent level. Because the WHT at source can decrease the net-of-tax income of investors, an increase in the WHT rate can discourage inward investment. ${ }^{22}$ However, the coefficients on the CIT rates in (1) turn out to be insignificant. ${ }^{23}$

In contrast, column (2) includes the two network variables but not the WHT rate variable. As expected, the coefficient on $T M D 1 R$ in (2) is positive and significant at the 1 percent level. The coefficient on TSA1R in (2) is negative and significant at the 5 percent level.

Columns (3) to (5) include different combinations of variables. Notably, in (3) and (5), the coefficients on TMD1R are positive and significant at the

\footnotetext{
${ }^{21}$ For instance, see Blonigen and Davies (2004), Louie and Rousslang (2008), Blonigen et al. (2014), and Dyreng et al. (2015).

${ }^{22}$ Dyreng et al. (2015) also find that, as the WHT rate increases, US multinational firms are more likely to use indirect ownership structures. The use of indirect structures can reduce FDI via a direct route.

${ }^{23}$ In columns (2) to (5), the coefficients on $C I T_{i}$, the CIT rate in residence country $i$, are negative and significant. Barrios et al. (2012) also find that corporate taxation of foreign-source dividends in residence countries is negatively related to the probability of foreign subsidiary location in potential source countries.
} 
Table 8. Effects of network variables (1R) on FDI instock

\begin{tabular}{|c|c|c|c|c|c|}
\hline & (1) & $(2)$ & $\begin{array}{c}I N S T K_{i j} \\
(3)\end{array}$ & (4) & (5) \\
\hline$T M D 1 R_{i j}$ & & $\begin{array}{c}4,175.44^{* * *} \\
(1523.52)\end{array}$ & $\begin{array}{c}4,050.98^{* * *} \\
(1500.93)\end{array}$ & & $\begin{array}{c}4,035.24^{* * *} \\
(1466.48)\end{array}$ \\
\hline$T S A 1 R_{i j}$ & & $\begin{array}{c}-207.75^{* *} \\
(83.68)\end{array}$ & & $\begin{array}{c}229.73 \\
(315.25)\end{array}$ & $\begin{array}{c}66.30 \\
(260.15)\end{array}$ \\
\hline$W H T_{j i}$ & $\begin{array}{c}-394.61^{* * *} \\
(80.46)\end{array}$ & & $\begin{array}{c}-209.22^{* * *} \\
(80.99)\end{array}$ & $\begin{array}{l}-614.76^{*} \\
(331.33)\end{array}$ & $\begin{array}{l}-273.47 \\
(241.04)\end{array}$ \\
\hline$C I T_{j}$ & $\begin{array}{c}14.35 \\
(128.04)\end{array}$ & $\begin{array}{c}18.58 \\
(127.86)\end{array}$ & $\begin{array}{c}-1.36 \\
(37.78)\end{array}$ & $\begin{array}{c}14.61 \\
(128.07)\end{array}$ & $\begin{array}{c}18.96 \\
(127.93)\end{array}$ \\
\hline$C I T_{i}$ & $\begin{array}{l}-40.53 \\
(32.01)\end{array}$ & $\begin{array}{c}-141.85^{* * *} \\
(49.91)\end{array}$ & $\begin{array}{l}-55.08^{*} \\
(33.28)\end{array}$ & $\begin{array}{c}-148.41^{* * *} \\
(50.56)\end{array}$ & $\begin{array}{c}-145.82^{* * *} \\
(50.75)\end{array}$ \\
\hline$T I N S T K_{j}$ & $\begin{array}{c}0.02^{* * *} \\
(0.004)\end{array}$ & $\begin{array}{c}0.02^{* * *} \\
(0.004)\end{array}$ & $\begin{array}{l}0.02^{* * *} \\
(0.004)\end{array}$ & $\begin{array}{c}0.02^{* * *} \\
(0.004)\end{array}$ & $\begin{array}{c}0.02^{* * *} \\
(0.004)\end{array}$ \\
\hline TOUTSTK $_{i}$ & $\begin{array}{l}0.01^{* * *} \\
(0.002)\end{array}$ & $\begin{array}{c}0.01^{* * *} \\
(0.002)\end{array}$ & $\begin{array}{c}0.01^{* * *} \\
(0.002)\end{array}$ & $\begin{array}{c}0.01^{* * *} \\
(0.002)\end{array}$ & $\begin{array}{c}0.01^{* * *} \\
(0.002)\end{array}$ \\
\hline Constant & $\begin{array}{l}-4,172.52 \\
(4477.76)\end{array}$ & $\begin{array}{l}-5,234.12 \\
(4788.88)\end{array}$ & $\begin{array}{c}-7,496.34^{* * *} \\
(2035.51)\end{array}$ & $\begin{array}{c}-457.97 \\
(4428.13)\end{array}$ & $\begin{array}{l}-5,029.65 \\
(4745.58)\end{array}$ \\
\hline Home Dummy & Yes & Yes & Yes & Yes & Yes \\
\hline Source Dummy & Yes & Yes & Yes & Yes & Yes \\
\hline $\begin{array}{c}\text { Observations } \\
\text { R-squared }\end{array}$ & $\begin{array}{l}4556 \\
0.20\end{array}$ & $\begin{array}{l}4556 \\
0.20\end{array}$ & $\begin{array}{l}4556 \\
0.20\end{array}$ & $\begin{array}{l}4556 \\
0.20\end{array}$ & $\begin{array}{l}4556 \\
0.20\end{array}$ \\
\hline
\end{tabular}

Note: Robust standard errors in parentheses; ${ }^{*}$ significant at $10 \% ;{ }^{* *}$ at $5 \%$; ${ }^{* * *}$ at $1 \%$

1 percent level, as expected. However, the coefficients on $T S A 1 R$ in (4) and (5) are insignificant. The treaty shopping arbitrage rate in case (1R) may not be statistically related to inward FDI stock. The coefficients on the WHT rates in (3) to (5) are negative, as expected, but turn out to be insignificant when the regression equation includes all the independent variables.

The empirical observation about $T M D 1 R$, summarized in the following remark, is consistent with a theoretical model (Hong, 2014).

Remark. The availability of a tax-minimizing direct route is positively and significantly related to inward FDI stock. Across all relevant regressions in Table 8, the coefficients on $T M D 1 R$ are positive and highly significant.

Therefore, by making a direct route tax-minimizing, countries can encourage foreign investment via the direct route and reduce treaty shopping, 


\section{4}

i.e., the use of indirect routes through conduit countries.

In Appendix A, Tables A.3 and A.4 present regression results with the other network variables. In Table A.4, overall, the results with $T M D 2 R$ and $T S A 2 R$ are similar to those with $T M D 1 R$ and $T S A 1 R$ in Table 8 . As expected, the coefficients on TMD2R are positive and significant. Moreover, the coefficients on $T M D 2 R$ are estimated to be larger than those on $T M D 1 R$. We can conclude that the availability of a tax-minimizing direct route in case $(2 \mathrm{R})$ is also positively related to FDI. However, in Table A.3, the coefficients on $T M D 1 S$ show mixed signs and are statistically insignificant. This may imply that the availability of a tax-minimizing direct route in case $(1 \mathrm{~S})$ is not statistically related to FDI.

\section{Conclusion}

In this paper, I construct a tax rate matrix to represent a tax treaty network and develop network algorithms to examine the structure of tax-minimizing investment routes. I find that the use of a tax-minimizing indirect route can substantially reduce tax on dividends incurred by a multinational investor. I also find that the availability of a tax-minimizing direct route is positively related to foreign investment via the direct route.

When a direct route is not tax-minimizing, to prevent the use of a taxminimizing indirect route, i.e., to prevent treaty shopping, countries need to consider negotiating a new tax treaty to make the direct route taxminimizing. These countries may not necessarily experience tax revenue loss, as the new treaty makes the direct route tax-minimizing and attracts more foreign investment.

For future studies, it will be interesting to investigate the network effect of LOB (limitation on benefits) provisions in tax treaties on the structure of tax-minimizing investment routes. In this paper, when constructing the tax rate matrix, I considered a restrictive version of LOB provisions that only allow certain pension funds to obtain the benefit of the lowest withholding tax rate. However, in real-world tax treaties, LOB provisions can impose 
various residency requirements. Therefore, it is important to examine how LOB provisions with various residency requirements affect the structure of tax-minimizing investment routes in tax treaty networks.

\section{Appendix A. Tables}

Table A.1 summarizes the result in case (2R) when each route passes through at most 2 countries and each pass-through country imposes CIT at the reduced rate. Table A.2 summarizes the result in case (2S) when each route passes through at most 2 countries and each pass-through country imposes CIT at the statutory rate. In Tables A.1 and A.2, column "Direct" shows the number of tax-minimizing direct routes to each source country. Column "1 Indirect" shows the number of tax-minimizing indirect routes with 1 pass-through country and column " 1 Indirect H" shows the number of residence countries with such routes. Column "2 Indirect" shows the number of tax-minimizing indirect routes with 2 pass-through countries and column "2 Indirect H" shows the number of residence countries with such routes. Column "TSA Mean" shows the average of treaty shopping arbitrage (TSA) rates for each source country.

Table A.3 shows regression results with network variables $T M D 1 S$ and $T S A 1 S$. Table A.4 shows regression results with TMD2R and TSA2R. Because the network variables in case $(2 \mathrm{~S})$ are the same as those in case (1S), regression results with $T M D 2 S$ and $T S A 2 S$ are omitted. 
Table A.1. Tax-minimizing routes $(2 \mathrm{R})$

\begin{tabular}{|c|c|c|c|c|c|c|}
\hline Source & Direct & 1 Indirect & 1 Indirect $\mathrm{H}$ & 2 Indirect & 2 Indirect $\mathrm{H}$ & TSA Mean \\
\hline AT & 33 & 464 & 36 & 0 & 0 & 6.83 \\
\hline $\mathrm{BE}$ & 61 & 162 & 8 & 0 & 0 & 2.78 \\
\hline BG & 30 & 398 & 39 & 0 & 0 & 2.26 \\
\hline $\mathrm{CA}$ & 40 & 494 & 29 & 0 & 0 & 4.46 \\
\hline $\mathrm{CN}$ & 31 & 590 & 38 & 0 & 0 & 2.11 \\
\hline HR & 31 & 426 & 38 & 0 & 0 & 4.99 \\
\hline $\mathrm{CZ}$ & 31 & 387 & 38 & 0 & 0 & 4.81 \\
\hline DK & 39 & 410 & 30 & 0 & 0 & 7.41 \\
\hline EG & 5 & 232 & 64 & 0 & 0 & 7.84 \\
\hline FI & 34 & 415 & 35 & 0 & 0 & 6.01 \\
\hline FR & 38 & 391 & 31 & 0 & 0 & 5.78 \\
\hline$\overline{\mathrm{DE}}$ & 31 & 386 & 38 & 0 & 0 & 6.62 \\
\hline GR & 30 & 398 & 39 & 0 & 0 & 4.51 \\
\hline IS & 30 & 398 & 39 & 0 & 0 & 8.06 \\
\hline ID & 1 & 68 & 68 & 0 & 0 & 8.24 \\
\hline IE & 54 & 245 & 15 & 0 & 0 & 4.13 \\
\hline IL & 5 & 220 & 64 & 0 & 0 & 12.71 \\
\hline IT & 31 & 386 & 38 & 0 & 0 & 7.35 \\
\hline JP & 9 & 318 & 60 & 0 & 0 & 10.62 \\
\hline KR & 1 & 18 & 18 & 610 & 50 & 7.38 \\
\hline LT & 32 & 411 & 37 & 0 & 0 & 6.13 \\
\hline $\mathrm{LU}$ & 35 & 438 & 34 & 0 & 0 & 4.14 \\
\hline MX & 19 & 610 & 50 & 0 & 0 & 5.04 \\
\hline NL & 40 & 391 & 29 & 0 & 0 & 4.07 \\
\hline $\mathrm{NO}$ & 33 & 433 & 36 & 0 & 0 & 7.59 \\
\hline PA & 1 & 68 & 68 & 0 & 0 & 8.28 \\
\hline $\mathrm{PE}$ & 1 & 38 & 38 & 445 & 30 & 0.63 \\
\hline $\mathrm{PH}$ & 1 & 31 & 31 & 378 & 37 & 7.04 \\
\hline $\mathrm{PL}$ & 31 & 421 & 38 & 0 & 0 & 6.36 \\
\hline $\mathrm{PT}$ & 30 & 398 & 39 & 0 & 0 & 8.06 \\
\hline $\mathrm{RO}$ & 31 & 421 & 38 & 0 & 0 & 6.41 \\
\hline $\mathrm{RU}$ & 27 & 562 & 42 & 0 & 0 & 3.91 \\
\hline $\mathrm{SA}$ & 3 & 121 & 53 & 514 & 13 & 3.64 \\
\hline SI & 30 & 398 & 39 & 0 & 0 & 6.29 \\
\hline $\mathrm{ZA}$ & 40 & 528 & 29 & 0 & 0 & 3.30 \\
\hline ES & 38 & 457 & 31 & 0 & 0 & 4.75 \\
\hline $\mathrm{SE}$ & 36 & 391 & 33 & 0 & 0 & 7.49 \\
\hline $\mathrm{CH}$ & 36 & 458 & 33 & 0 & 0 & 6.36 \\
\hline TW & 17 & 218 & 52 & 0 & 0 & 6.60 \\
\hline $\mathrm{TH}$ & 69 & 0 & 0 & 0 & 0 & 0.00 \\
\hline TR & 15 & 446 & 54 & 0 & 0 & 5.20 \\
\hline UA & 5 & 160 & 42 & 1241 & 22 & 7.19 \\
\hline US & 12 & 393 & 57 & 0 & 0 & 11.97 \\
\hline UY & 13 & 350 & 56 & 0 & 0 & 0.85 \\
\hline
\end{tabular}

Note: (2R) at most 2 pass-through countries and Reduced CIT rates 
Table A.2. Tax-minimizing routes $(2 \mathrm{~S})$

\begin{tabular}{|c|c|c|c|c|c|c|}
\hline Source & Direct & 1 Indirect & 1 Indirect $\mathrm{H}$ & 2 Indirect & 2 Indirect $\mathrm{H}$ & TSA Mean \\
\hline AT & 33 & 68 & 68 & 201 & 68 & 7.35 \\
\hline $\mathrm{BE}$ & 61 & 68 & 68 & 201 & 68 & 2.90 \\
\hline BG & 69 & 152 & 39 & 444 & 39 & 0.00 \\
\hline $\mathrm{CA}$ & 40 & 68 & 68 & 201 & 68 & 4.86 \\
\hline $\mathrm{CN}$ & 33 & 37 & 37 & 108 & 37 & 1.54 \\
\hline HR & 43 & 28 & 28 & 84 & 22 & 0.88 \\
\hline $\mathrm{CZ}$ & 46 & 37 & 37 & 108 & 37 & 2.61 \\
\hline DK & 48 & 27 & 27 & 88 & 23 & 3.80 \\
\hline EG & 5 & 68 & 68 & 201 & 68 & 8.77 \\
\hline FI & 34 & 68 & 68 & 201 & 68 & 6.52 \\
\hline FR & 38 & 68 & 68 & 201 & 68 & 6.23 \\
\hline$\overline{D E}$ & 48 & 37 & 37 & 108 & 37 & 4.42 \\
\hline GR & 38 & 38 & 38 & 111 & 38 & 2.25 \\
\hline IS & 39 & 32 & 32 & 104 & 27 & 3.59 \\
\hline ID & 34 & 67 & 67 & 201 & 68 & 4.25 \\
\hline $\mathrm{IE}$ & 54 & 68 & 68 & 201 & 68 & 4.35 \\
\hline IL & 39 & 30 & 30 & 72 & 19 & 4.07 \\
\hline IT & 40 & 37 & 37 & 108 & 37 & 5.14 \\
\hline JP & 21 & 59 & 59 & 177 & 60 & 7.14 \\
\hline KR & 34 & 67 & 67 & 198 & 67 & 4.16 \\
\hline LT & 32 & 68 & 68 & 201 & 68 & 6.67 \\
\hline $\mathrm{LU}$ & 52 & 66 & 34 & 192 & 34 & 2.17 \\
\hline MX & 19 & 68 & 68 & 201 & 68 & 5.77 \\
\hline NL & 50 & 28 & 28 & 81 & 28 & 2.39 \\
\hline $\mathrm{NO}$ & 47 & 26 & 26 & 92 & 24 & 3.67 \\
\hline $\mathrm{PA}$ & 9 & 66 & 66 & 195 & 66 & 4.35 \\
\hline $\mathrm{PE}$ & 69 & 268 & 68 & 792 & 68 & 0.00 \\
\hline $\mathrm{PH}$ & 20 & 67 & 67 & 198 & 67 & 3.55 \\
\hline $\mathrm{PL}$ & 31 & 68 & 68 & 201 & 68 & 6.91 \\
\hline $\mathrm{PT}$ & 37 & 38 & 38 & 111 & 38 & 5.80 \\
\hline $\mathrm{RO}$ & 31 & 68 & 68 & 201 & 68 & 6.96 \\
\hline $\mathrm{RU}$ & 64 & 61 & 20 & 156 & 15 & 0.14 \\
\hline SA & 69 & 260 & 66 & 768 & 66 & 0.00 \\
\hline SI & 39 & 38 & 38 & 111 & 38 & 4.03 \\
\hline$\overline{\mathrm{ZA}}$ & 47 & 22 & 22 & 52 & 14 & 0.32 \\
\hline $\mathrm{ES}$ & 46 & 30 & 30 & 90 & 31 & 2.96 \\
\hline SE & 52 & 24 & 24 & 80 & 21 & 3.91 \\
\hline $\mathrm{CH}$ & 50 & 32 & 32 & 96 & 33 & 4.45 \\
\hline TW & 21 & 48 & 48 & 92 & 24 & 1.17 \\
\hline TH & 69 & 268 & 68 & 792 & 68 & 0.00 \\
\hline TR & 41 & 53 & 53 & 159 & 54 & 2.03 \\
\hline UA & 38 & 63 & 63 & 189 & 64 & 3.80 \\
\hline US & 44 & 25 & 25 & 76 & 20 & 4.78 \\
\hline UY & 69 & 220 & 56 & 648 & 56 & 0.00 \\
\hline
\end{tabular}

Note: (2S) at most 2 pass-through countries and Statutory CIT rates 
Table A.3. Effects of network variables (1S) on FDI instock

\begin{tabular}{c|ccccc}
\hline & $(1)$ & $(2)$ & $(3)$ & $(4)$ & $(5)$ \\
\hline$T M D 1 S_{i j}$ & & $2,129.45$ & $-1,733.74$ & & $-1,307.11$ \\
& & $(1482.63)$ & $(1920.98)$ & & $(1839.73)$ \\
$T S A 1 S_{i j}$ & & $-196.71^{* *}$ & & $763.23^{* *}$ & $750.27^{* *}$ \\
& & $(78.08)$ & & $(302.98)$ & $(294.88)$ \\
$W H T_{j i}$ & $-394.61^{* * *}$ & & $-486.37^{* * *}$ & $-966.44^{* * *}$ & $-1,025.91^{* * *}$ \\
& $(80.46)$ & & $(140.71)$ & $(293.00)$ & $(334.09)$ \\
CIT & 14.35 & 0.96 & 16.61 & 29.94 & 31.38 \\
& $(128.04)$ & $(127.35)$ & $(128.57)$ & $(129.46)$ & $(129.90)$ \\
CIT & $-146.07^{* * *}$ & $-109.72^{* *}$ & $-147.30^{* * *}$ & $-145.26^{* * *}$ & $-146.20^{* * *}$ \\
& $(50.00)$ & $(47.34)$ & $(50.22)$ & $(50.63)$ & $(50.74)$ \\
$T I N S T K_{j}$ & $0.02^{* * *}$ & $0.02^{* * *}$ & $0.02^{* * *}$ & $0.02^{* * *}$ & $0.02^{* * *}$ \\
& $(0.004)$ & $(0.004)$ & $(0.004)$ & $(0.005)$ & $(0.005)$ \\
TOUTSTK $K_{i}$ & $0.01^{* * *}$ & $0.01^{* * *}$ & $0.01^{* * *}$ & $0.01^{* * *}$ & $0.01^{* * *}$ \\
& $(0.002)$ & $(0.002)$ & $(0.002)$ & $(0.002)$ & $(0.002)$ \\
Constant & -478.41 & $-3,026.97$ & $1,248.59$ & $-1,385.00$ & -67.57 \\
& $(4427.74)$ & $(4737.11)$ & $(4521.53)$ & $(4520.16)$ & $(4555.67)$ \\
\hline Home Dummy & Yes & Yes & Yes & Yes & Yes \\
Source Dummy & Yes & Yes & Yes & Yes & Yes \\
\hline Observations & 4556 & 4556 & 4556 & 4556 & 4556 \\
R-squared & 0.20 & 0.20 & 0.20 & 0.20 & 0.20 \\
\hline
\end{tabular}

Note: Robust standard errors in parentheses; * significant at $10 \%$; ** at $5 \%$; *** at $1 \%$ 
Table A.4. Effects of network variables (2R) on FDI instock

\begin{tabular}{|c|c|c|c|c|c|}
\hline & (1) & (2) & $\begin{array}{c}I N S T K_{i j} \\
(3)\end{array}$ & (4) & (5) \\
\hline$T M D 2 R_{i j}$ & & $\begin{array}{c}5,110.26^{* * *} \\
(1803.15)\end{array}$ & $\begin{array}{c}4,973.08^{* * *} \\
(1841.94)\end{array}$ & & $\begin{array}{c}5,400.87^{* * * *} \\
(1834.90)\end{array}$ \\
\hline$T S A 2 R_{i j}$ & & $\begin{array}{c}-182.65^{* *} \\
(85.19)\end{array}$ & & $\begin{array}{c}1,441.96 \\
(1093.80)\end{array}$ & $\begin{array}{l}-489.44 \\
(311.41)\end{array}$ \\
\hline$W H T_{j i}$ & $\begin{array}{c}-394.61^{* * *} \\
(80.46)\end{array}$ & & $\begin{array}{c}-179.35^{* *} \\
(84.74)\end{array}$ & $\begin{array}{c}-1,772.74^{*} \\
(1069.74)\end{array}$ & $\begin{array}{c}306.95 \\
(301.66)\end{array}$ \\
\hline$C I T_{j}$ & $\begin{array}{c}14.35 \\
(128.04)\end{array}$ & $\begin{array}{c}20.5 \\
(127.89)\end{array}$ & $\begin{array}{c}-1.36 \\
(37.68)\end{array}$ & $\begin{array}{c}15.97 \\
(128.01)\end{array}$ & $\begin{array}{c}20.46 \\
(127.90)\end{array}$ \\
\hline$C I T_{i}$ & $\begin{array}{l}-40.53 \\
(32.01)\end{array}$ & $\begin{array}{c}-63.33^{*} \\
(34.32)\end{array}$ & $\begin{array}{c}-152.30 * * * \\
(50.71)\end{array}$ & $\begin{array}{l}-48.32 \\
(32.89)\end{array}$ & $\begin{array}{c}-151.33^{* * *} \\
(50.77)\end{array}$ \\
\hline TINSTK $_{j}$ & $\begin{array}{c}0.02^{* * *} \\
(0.004)\end{array}$ & $\begin{array}{c}0.02^{* * *} \\
(0.004)\end{array}$ & $\begin{array}{c}0.02^{* * *} \\
(0.004)\end{array}$ & $\begin{array}{c}0.02^{* * *} \\
(0.004)\end{array}$ & $\begin{array}{c}0.02^{* * *} \\
(0.004)\end{array}$ \\
\hline TOUTSTK $_{i}$ & $\begin{array}{c}0.01^{* * *} \\
(0.002)\end{array}$ & $\begin{array}{c}0.01^{* * *} \\
(0.002)\end{array}$ & $\begin{array}{c}0.01^{* * *} \\
(0.002)\end{array}$ & $\begin{array}{c}0.01^{* * *} \\
(0.002)\end{array}$ & $\begin{array}{c}0.01^{* * *} \\
(0.002)\end{array}$ \\
\hline Constant & $\begin{array}{r}-4,172.52 \\
(4477.76)\end{array}$ & $\begin{array}{c}-9,216.70^{*} \\
(4921.41)\end{array}$ & $\begin{array}{c}-5,206.38^{* *} \\
(2615.03)\end{array}$ & $\begin{array}{r}-4,140.51 \\
(4475.87)\end{array}$ & $\begin{array}{r}-6,414.39 \\
(4920.57)\end{array}$ \\
\hline Home Dummy & Yes & Yes & Yes & Yes & Yes \\
\hline Source Dummy & Yes & Yes & Yes & Yes & Yes \\
\hline Observations & 4556 & 4556 & 4556 & 4556 & 4556 \\
\hline R-squared & 0.20 & 0.20 & 0.20 & 0.20 & 0.20 \\
\hline
\end{tabular}

Note: Robust standard errors in parentheses; * significant at $10 \%$; ** at $5 \%$; *** at $1 \%$ 


\section{Appendix B. Network Diagrams}

Figure B.1. Tax-minimizing routes (1R) to Mexico

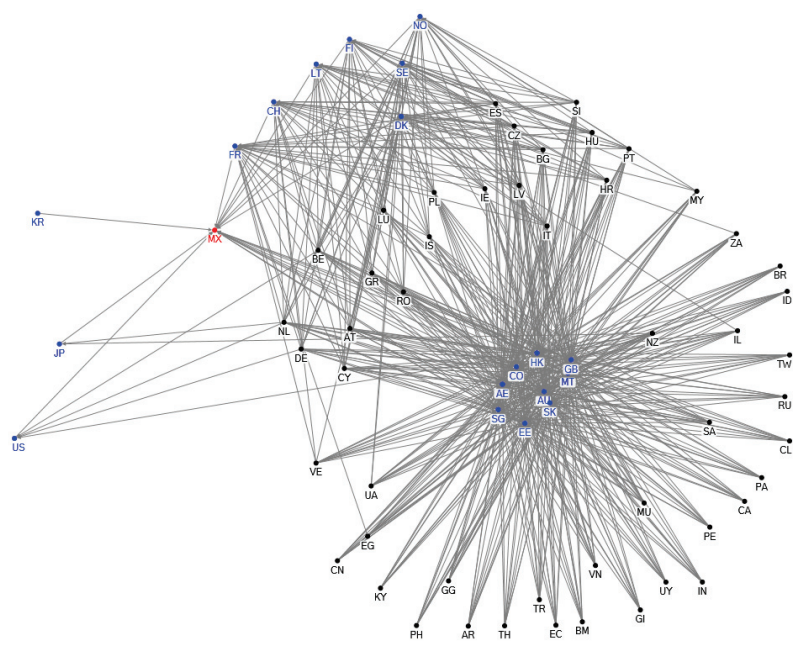

Note: source in red; countries with tax-minimizing direct routes in blue

Figure B.2. Tax-minimizing routes (1R) to Indonesia

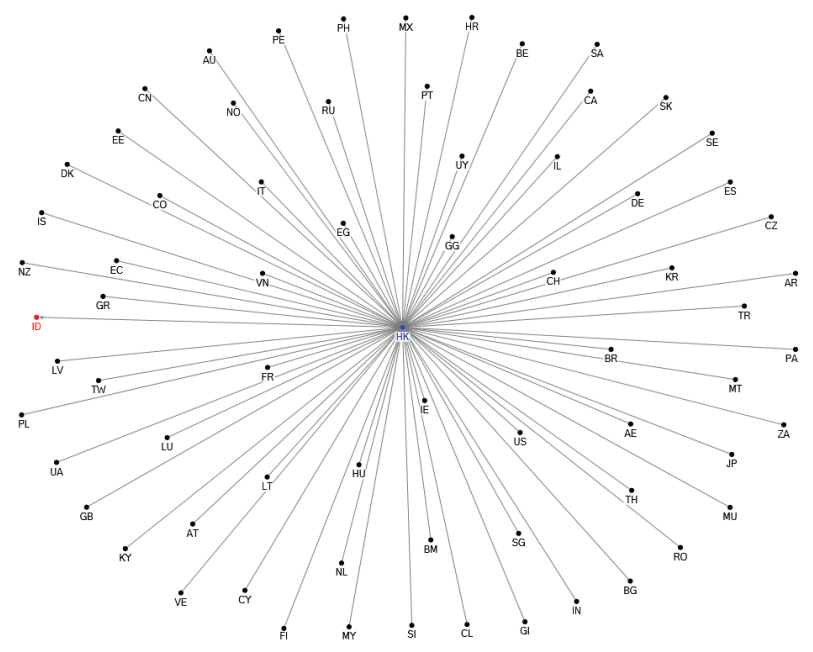

Note: source in red; countries with tax-minimizing direct routes in blue 
Figure B.3. Tax-minimizing routes (1R) to Poland

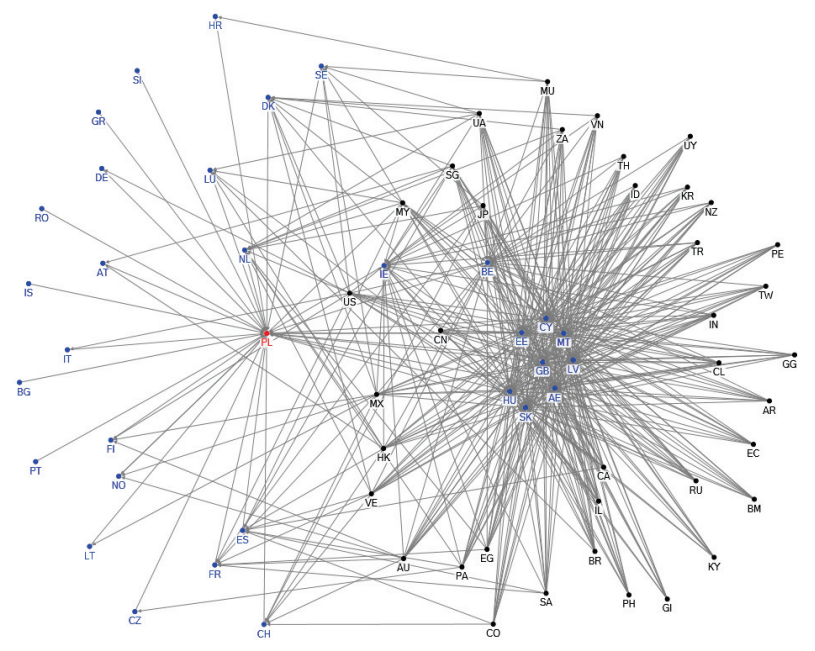

Note: source in red; countries with tax-minimizing direct routes in blue

Figure B.4. Tax-minimizing routes (1R) to Saudi Arabia

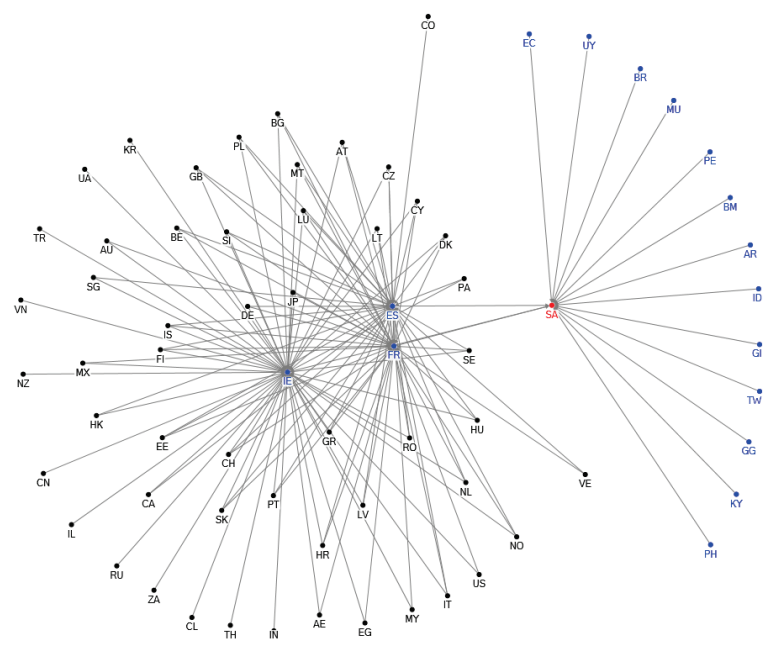

Note: source in red; countries with tax-minimizing direct routes in blue 
Figure B.5. Tax-minimizing routes (1R) from Japan

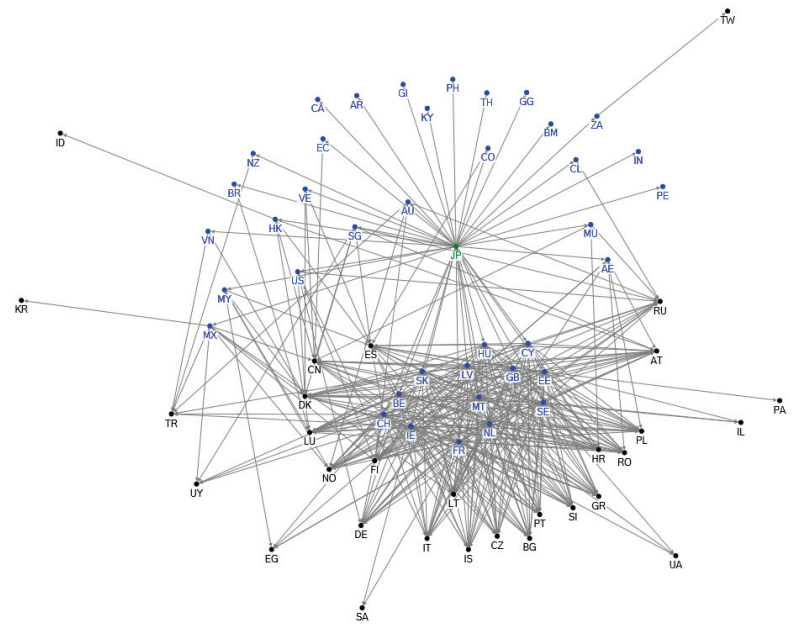

Note: residence in green; countries with tax-minimizing direct routes in blue

Figure B.6. Tax-minimizing routes (1R) from France

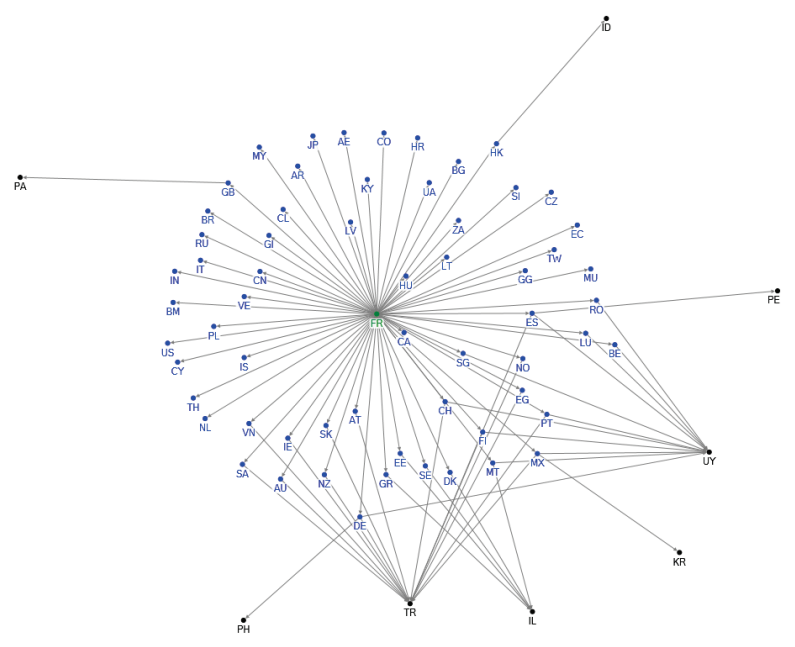

Note: residence in green; countries with tax-minimizing direct routes in blue 
Figure B.7. Tax-minimizing routes (1R) from Germany

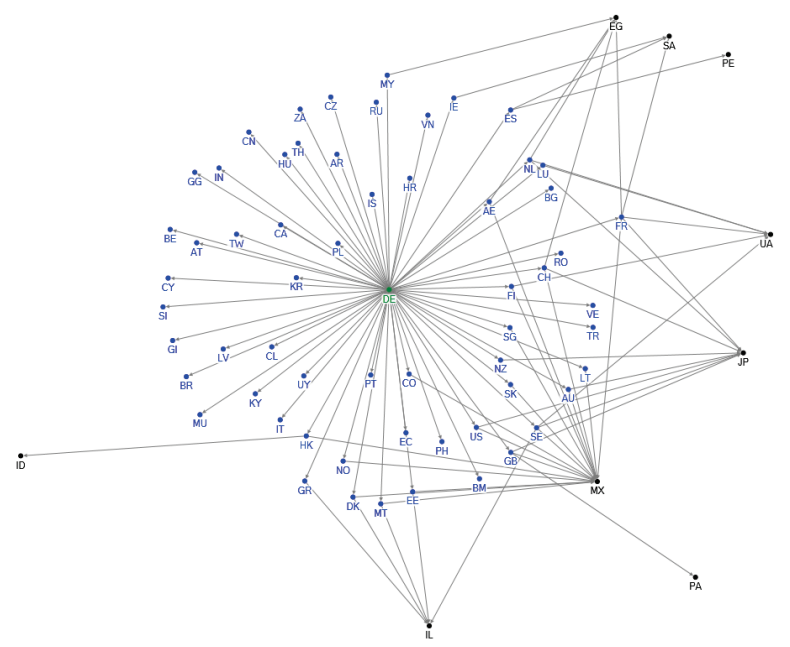

Note: residence in green; countries with tax-minimizing direct routes in blue

Figure B.8. Tax-minimizing routes (1R) from the United Kingdom

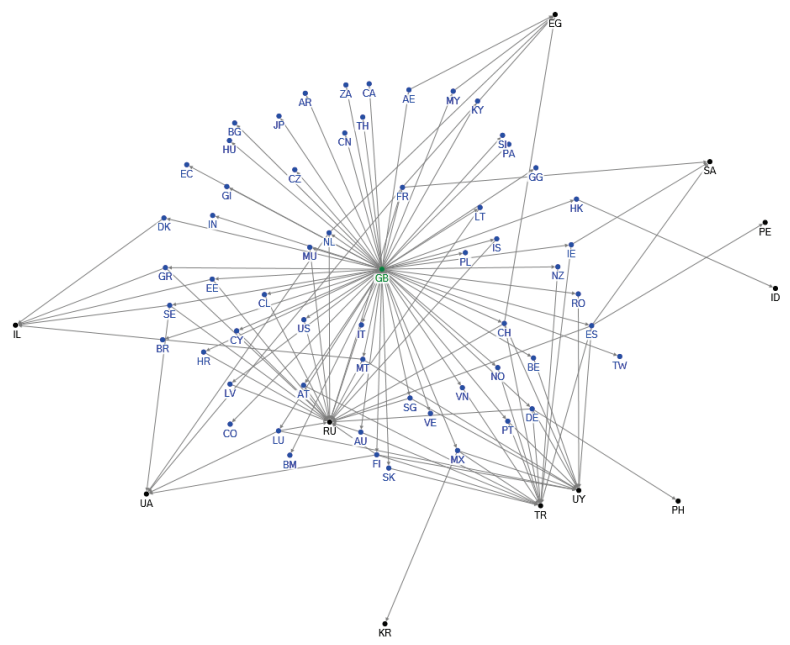

Note: residence in green; countries with tax-minimizing direct routes in blue 


\section{References}

[1] Barrios, Salvador, Harry Huizinga, Luc Laeven, and Gaëtan Nicodème. 2012. "International Taxation and Multinational Firm Location Decisions." Journal of Public Economics, 96(11-12): 946-958.

[2] Becker, Johannes, Clemens Fuest, and Nadine Riedel. 2012. "Corporate Tax Effects on the Quality and Quantity of FDI." European Economic Review, 56(8): 1495-1511.

[3] Becker, Johannes, and Nadine Riedel. 2012. "Cross-Border Tax Effects on Affiliate Investment - Evidence from European Multinationals." European Economic Review, 56(3): 436-450.

[4] Blonigen, Bruce A., and Ronald B. Davies. 2004. "The Effects of Bilateral Tax Treaties on U.S. FDI Activity." International Tax and Public Finance, 11(5): 601-622.

[5] Blonigen, Bruce A., Lindsay Oldenski, and Nicholas Sly. 2014. "The Differential Effects of Bilateral Tax Treaties." American Economic Journal: Economic Policy, 6(2): 1-18.

[6] Davies, Ronald B. 2004. "Tax Treaties and Foreign Direct Investment: Potential versus Performance." International Tax and Public Finance, 11(6): 775-802.

[7] Desai, Mihir A., C. Fritz Foley, and James R. Hines Jr. 2004. "Foreign Direct Investment in a World of Multiple Taxes." Journal of Public Economics, 88(12): 2727-2744.

[8] Devereux, Michael P., Clemens Fuest, and Ben Lockwood. 2015. "The Taxation of Foreign Profits: A Unified View." Journal of Public Economics, 125: 83-97. 
[9] di Giovanni, Julian. 2005. "What Drives Capital Flows? The Case of Cross-Border M\&A Activity and Financial Deepening." Journal of International Economics, 65(1): 127-149.

[10] Dischinger, Matthias, and Nadine Riedel. 2011. "Corporate Taxes and the Location of Intangible Assets within Multinational Firms." Journal of Public Economics, 95(7-8): 691-707.

[11] Dyreng, Scott D., Bradley P. Lindsey, Kevin S. Markle, and Douglas A. Shackelford. 2015. "The Effect of Tax and Nontax Country Characteristics on the Global Equity Supply Chains of U.S. Multinationals." Journal of Accounting and Economics, 59(2-3): 182-202.

[12] Hong, Sunghoon. 2014. "Strategic Treaty Shopping." working paper.

[13] Huizinga, Harry, and Johannes Voget. 2009. "International Taxation and the Direction and Volume of Cross-Border M\&As." Journal of Finance, 64(3): 1217-1249.

[14] Johannesen, Niels. 2012. "Optimal Fiscal Barriers to International Economic Integration in the Presence of Tax Havens." Journal of Public Economics, 96(3-4): 400-416.

[15] Lewellen, Katharina, and Leslie Robinson. 2013. "Internal Ownership Structures of U.S. Multinational Firms." working paper.

[16] Louie, Henry J., and Donald J. Rousslang. 2008. "Host-Country Governance, Tax Treaties and US Direct Investment Abroad." International Tax and Public Finance, 15(3): 256-273.

[17] Mintz, Jack M., and Alfons J. Weichenrieder. 2010. The Indirect Side of Direct Investment. Cambridge, MA: MIT Press.

[18] Mooij de, Ruud A., and Sjef Ederveen. 2003. "Taxation and Foreign Direct Investment: A Synthesis of Empirical Research." International Tax and Public Finance, 10(6): 673-693. 
Tax Treaties and Foreign Direct Investment: A Network Approach

46

[19] Mutti, John, and Harry Grubert. 2004. "Empirical Asymmetries in Foreign Direct Investment and Taxation." Journal of International Economics, 62(2): 337-358.

[20] van’t Riet, Maarten, and Arjan Lejour. 2015. "Profitable Detours: Network Analysis of Tax Treaty Shopping." working paper.

[21] Voget, Johannes. 2011. "Relocation of Headquarters and International Taxation." Journal of Public Economics, 95(9-10): 1067-1081.

[22] Weyzig, Francis. 2013. "Tax Treaty Shopping: Structural Determinants of Foreign Direct Investment Routed Through the Netherlands." International Tax and Public Finance, 20(6): 910-937. 